\title{
The Power of Puppets in Storytelling \& its Cultural Influence on Museum Experience Design
}

Nermine Moustafa

\begin{abstract}
The purpose of this paper is to study the possibility of using storytelling puppets in designing the museum experiences to increase the engagement of museum visitors, based on their cultural influence.

In the first part, the research explains the terminology \& a theoretical study. The second part studies the classifications of puppets, discussing the concept of storytelling, and how it is related to the design process, in terms of cultural influence. The third part includes a fieldwork to know what people expect from museums, and generate recommendations from their answers.
\end{abstract}

\section{Keywords}

\#Puppets\#Storytelling\#Cultural_Influence\#Museum_Experience_Design\#Museum_ Education\#Museum_Marketing

\section{Introduction}

Puppets have a strong effect on a people. This can help in facilitating the interpretation of museums, telling stories behind objects in creative ways that make people more interested.

Integrating puppets in museums can be done in many forms to engage people, turning the boring museum experience into a very interesting one. Museums will no longer be observed as tombs, as the visitors' impressions will be transformed. They will be able to visit museums over and over to learn and have fun.

\subsection{Hypothesis}

- Does Museum-Experience-Design require special considerations?

- Can we benefit from the influence of puppets on the Egyptian culture in designing experiences in Egyptian Museums?

\subsection{Objectives}

- To study the Experience-Design concept.

- To study Storytelling \& criteria of successful communication in museums.

- To study the history \& types of puppets \& their cultural influence on people.

- To study some of the international practices of using puppets in museums.

- To suggest ideas to integrate puppets in the Egyptian Museums in terms of Experience-Design \& storytelling Concepts.

\subsection{Methodology}

- Theoretical Study: It will trace the history of puppets, from the earliest known till nowadays.

- Practical Study: It will include a study of the classifications of puppets, some examples from Egyptian \& International museums that use puppets, followed by the concept of storytelling, 
requirements of successful communication, explaining how it is related to the design process, in terms of Experience Design \& Cultural influence.

- Analytical Studies A field study will be undertaken based on Questionnaires, Interviews, followed by a result analysis that will be conducted to get the findings required to generate creative suggestions for museum practices.

\subsection{Terminology}

1.4.1 Puppet: An artificial figure representing a human being or an animal, or a mythical figure, manipulated by the hand, rods, wires, etc., ${ }^{1}$

1.4.2 Puppetry:A form of theatre or performance that involves the manipulation of puppets, manipulated by a human called a puppeteer ${ }^{2}$

1.4.3 Storytelling: The social and cultural activity of sharing stories. Stories or narratives have been shared in every culture as a means of entertainment, education, cultural preservation and instilling moral values. ${ }^{3}$

1.4.4 Culture: A collective programming of the mind that distinguishes the members of one group or category of people from another. ${ }^{4}$

1.4.5 Experience Design XD: The practice of designing products, processes, services, events, omnichannel journeys, and environments with a focus placed on the quality of the user experience and culturally relevant solutions ${ }^{5}$, with a focus on the creation and delivery of value (utility, meaning, etc.). ${ }^{6}$

\subsection{History of Puppets:}

Puppetry is a very ancient form of art performance that is thought to have originated about 3000 years ago, to animate and communicate the ideas and needs of human societies.

\subsubsection{Puppets in Egypt:}

There is evidence that puppets were used in Egypt as early as $2000 \mathrm{BC}$ when string-operated figures of wood were manipulated to perform the action of kneading bread. ${ }^{7}$

\footnotetext{
${ }^{1}$ Collins Dictionary, "Puppetry," Accessed September 4, 2017, https://www.collinsdictionary.com/dictionary/english/puppet

${ }^{2}$ ibid, https://www.collinsdictionary.com/dictionary/english/puppetry

${ }^{3}$ Cajete, Gregory, Donna Eder and Regina Holyan. “Life Lessons through Storytelling: Childrenss Exploration of Ethics”. Bloomington: Indiana UP, 2010

${ }^{4}$ Texas A\&M University, “Culture,” Accessed September 3, 2017, https://tlac.tamu.edu/

${ }^{5}$ Emile H. L., and Stefano Marzano, "The New Everyday: Views on Ambient Intelligence”. 010 Publishers, 2003, 46.

${ }^{6}$ Patrick Newbery, "Experience Design is a Perspective not a Discipline," UX Magazine, 2013, http://uxmag.com/articles/experience-design-is-aperspective-not-a-discipline

${ }^{7}$ Fernando Guimarães, “Puppetry: An Overview”, Pedia Press, 1997, 50.
} 


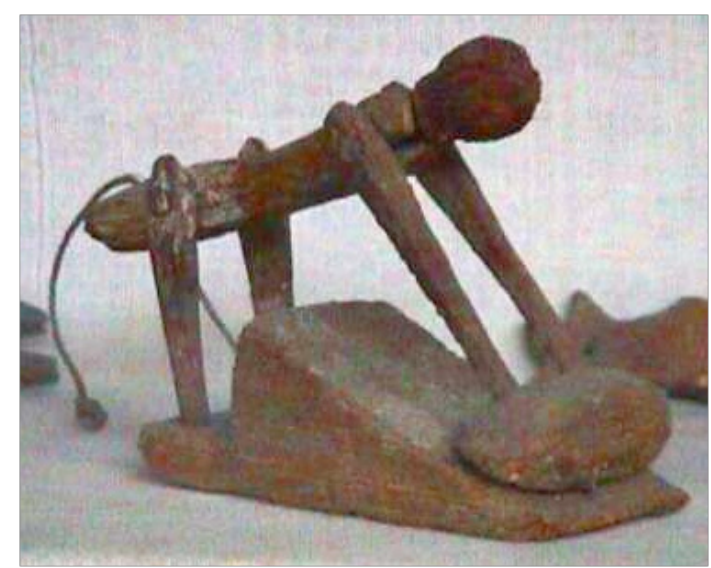

Fig. (1) String operated figure kneading dough, Egypt, 2000 BC. ${ }^{8}$

The earliest puppets probably originated in Egypt, where ivory and clay articulated puppets have been discovered in tombs. Puppets are mentioned in writing as early as 422 B.C.E. In ancient Greece, Aristotle and Plato both made reference to puppetry. ${ }^{9}$

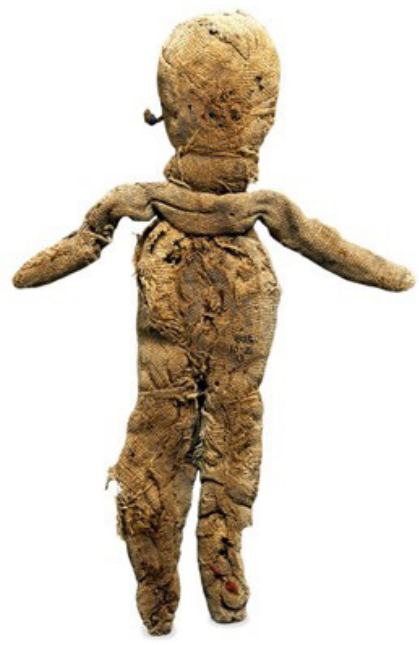

Fig. (2) Rag-doll from linen stuffed with rags and papyrus - British Museum ${ }^{10}$

\subsubsection{Puppets in Popular Egyptian Culture Through History:}

\subsubsection{Nile Bride:}

Nile Bride or "Arouset Alnil", is a wooden doll, used in celebrating the tribute to the river Nile, since the ancient times of the Pharaonic era according to old myths. On this occasion, Egyptians have never thrown a human sacrifice into the Nile ${ }^{11}$.

\footnotetext{
${ }^{8}$ Keith Rawlings, "Observation on the Historical development of puppetry," Accessed Mach 3, 2017, http://pages.citenet.net/users/ctmw2400/ chapter 1.html

${ }^{9}$ Theater Seat Store, "History of Puppetry,” Accessed September 17, 2017, https://www.theaterseatstore.com/history-of-puppetry

10 The British Museum, “Collection Online: Rag Doll,” Accessed August 18, 2017, http://www.britishmuseum.org/research/collection_online/ collection_object_details.aspx?objectId=400067\&partId=1

${ }^{11}$ Samar Alnajjar, “Arous-Alnil bayna Al-Ostoura wal-haqiqah fel-Cinema Al-misreyah” (The Nile Bride between myth \& reality in the Egyptian Cinema), Garidat El-masry El-yom (The Egtptian Today Newspaper), August 18, 2017.
} 


\subsubsection{Evil-Eye (Envy Treatment) Doll:}

It was found that the use of figures in Black Magic is commonly known as envoutement, which means the act of making a figure of wax (or mud, or any other substance) of a certain person, with the intention, after having performed upon it certain baleful acts and ceremonies, of making the person suffer all the pains and indignities which the magician inflicts on the wax figure.

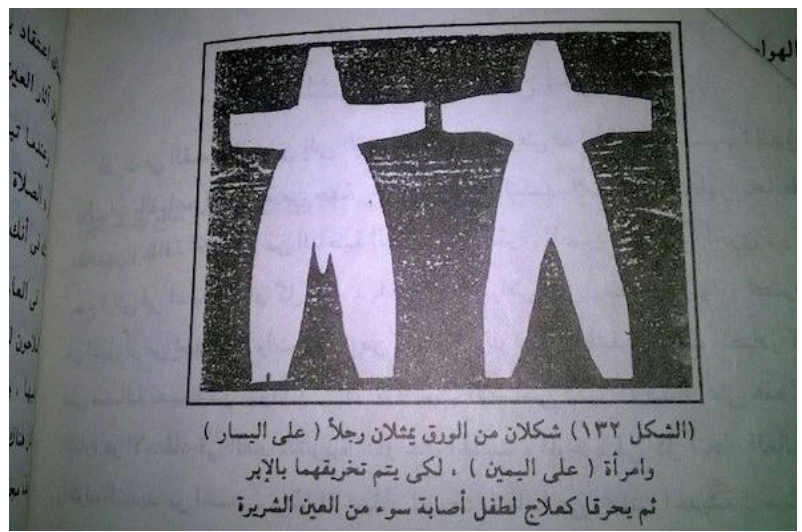

Fig. (3) A couple of paper figures resembling human abstractive body, on the left side of the photo is a masculine figure, while a feminine one is on the right side. These figures were used in envy treatment, for children who were believed to be affected by Evil Eyes. ${ }^{12}$

\subsubsection{Karagoz:}

Karagöz is a form of Turkish shadow theatre in which figures are made of Camel or Ox leather in the shape of people, held on rods in front of a light source to cast their shadows onto a cotton screen. The traditional theatre strengthens a sense of cultural identity while bringing people closer together through entertainment.

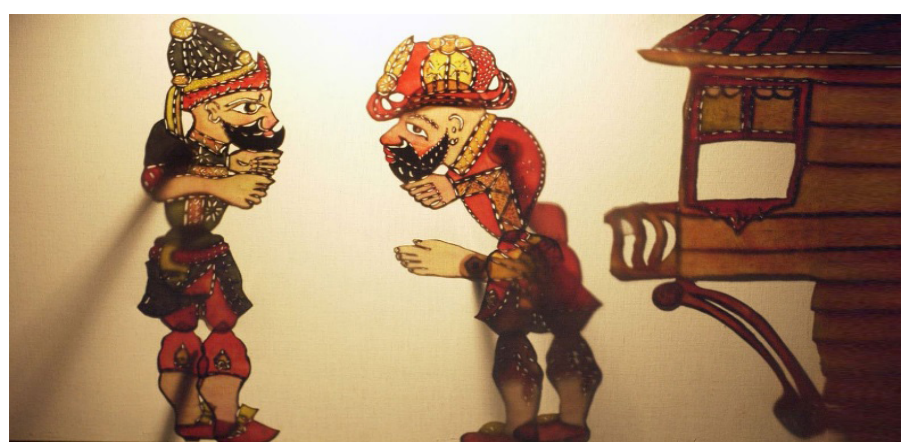

Fig. (4) Turkish karagooz shadow puppet theatre. ${ }^{13}$

Egyptian culture was inspired by the Turkish Karagoz in the $16^{\text {th }}$ century as a result of the cultural influence that took place during the Ottoman existence in Egypt, developing an Egyptian version of it. ${ }^{14}$

\subsubsection{The Bride Doll of Al-Mulid:}

The candy puppet or the bride of Al-Mulid, is considered one of the icons of folklore that captured the hearts and minds of the Egyptians, as a symbol of the Prophet's birth until now.

\footnotetext{
${ }^{12}$ E.A, and Wallis Budge, "From Fetish to God in Ancient Egypt," Routledge, 2013, 128.

${ }^{13}$ UNESCO Multimedia Archives eServices, “Culture: Intangible Heritage, Karagöz,” Accessed August 12, 2017, http://www.unesco.org/archives/ multimedia/?pg=33\&s=films_details\&id=365

${ }^{14} \mathrm{ibid}$
} 


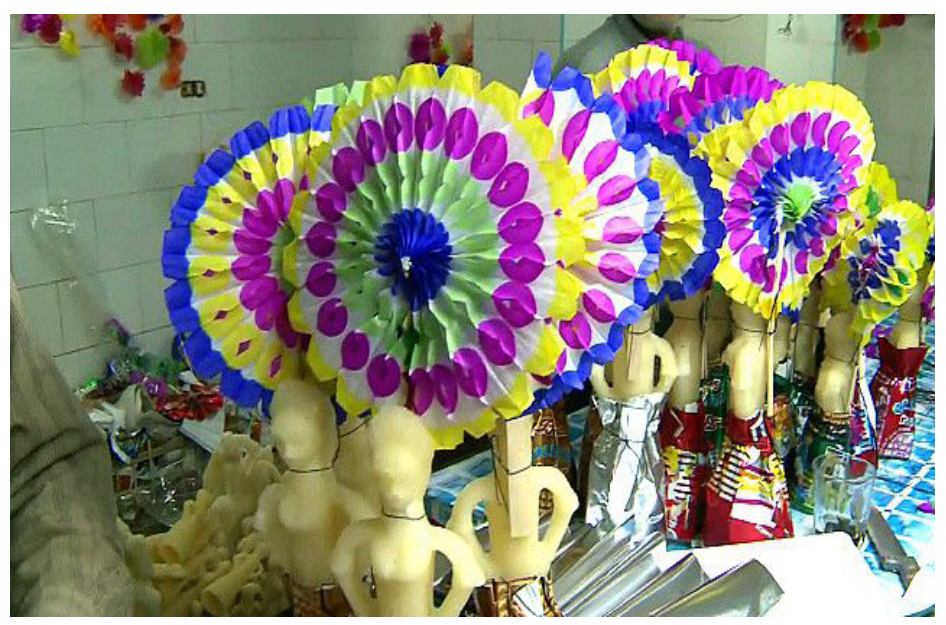

Fig. (5) The Bride of Al-Mulid from sugar..$^{15}$

\subsubsection{Shabti Doll:}

Shabti dolls (Shawbti/Ushabti) were funerary figures in ancient Egypt who accompanied the deceased to theafter-life. ${ }^{16}$

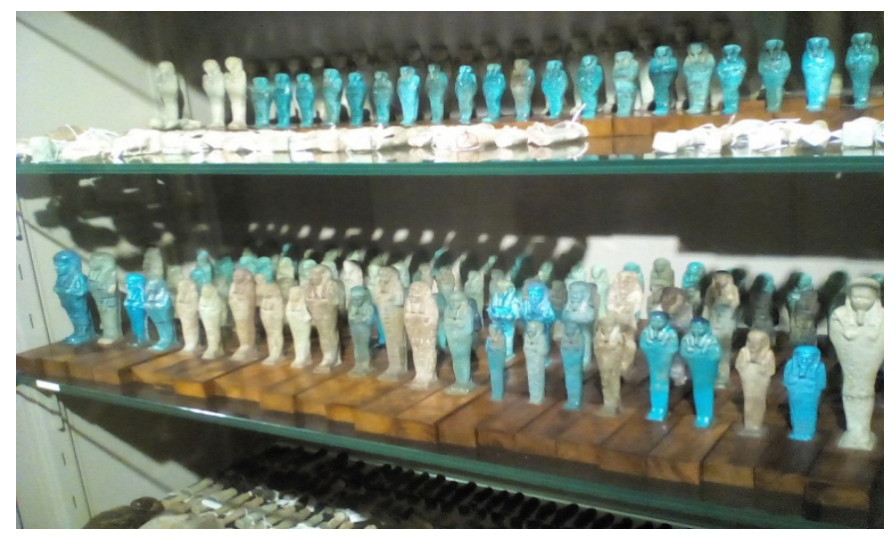

Fig. (6) Shabti dolls from stones and faience at the Egyptian Museum in Turin, Italy. ${ }^{17}$

\subsubsection{Paddle Doll:}

The Paddle Doll consists of a flat piece of wood depicting the torso, rudimentary arms and neck of a woman, with a thick shock of "hair" made of beads strung on linen thread, and was used as percussion instruments during religious ceremonies. ${ }^{18}$

\footnotetext{
${ }^{15}$ Mahmoud Aboubakr, "Arouset-Almawlid tuwajeh munafasah dareyah fi Misr" (The Bride-doll of celebrating The Prophet's-Birth Confronts Fierce Competition in Egypt), BBC-Arabic, December 22, 2015 http://www.bbc.com/arabic/multimedia/2015/12/151222_egypt_almawlid_alnabawi_ sweet

${ }^{16}$ Joshua J. Mark, "Shabti Dolls: The Workforce in the Afterlife," Ancient History Encyclopaedia, January 18, 2012, http://www.ancient.eu/article/1 19/

${ }^{17}$ Nermine Moustafa, "Shabti Dolls Displayed at The Material Multure Hall”, The Egyptian Museum in Turin, Feb 1, 2016,-,

18 THE MET, "Paddle Doll," Accessed September 1, 2017, http://www.metmuseum.org/art/collection/search/544216
} 


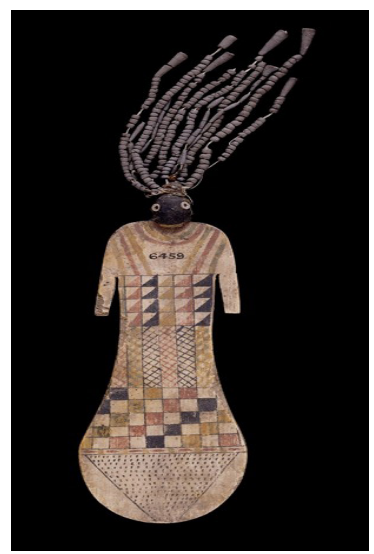

Fig.(7) Wooden paddle doll from the ancient Egypt \& Sudan collection - British museum. Middle kingdom or the first intermediate period. ${ }^{19}$

\subsection{Classification of Puppets, Experience Design, \& Cultural Influence:}

\subsection{Types of Puppets:}

Puppets can be classified according to their material, or by the way they move, or by their origin or the function they perform. There are more than forty types of puppets known worldwide, like Cantastoria, Rod, Animatronic Puppet, Glove puppet, the Marionette puppet, and the Shadow Puppet...etc.
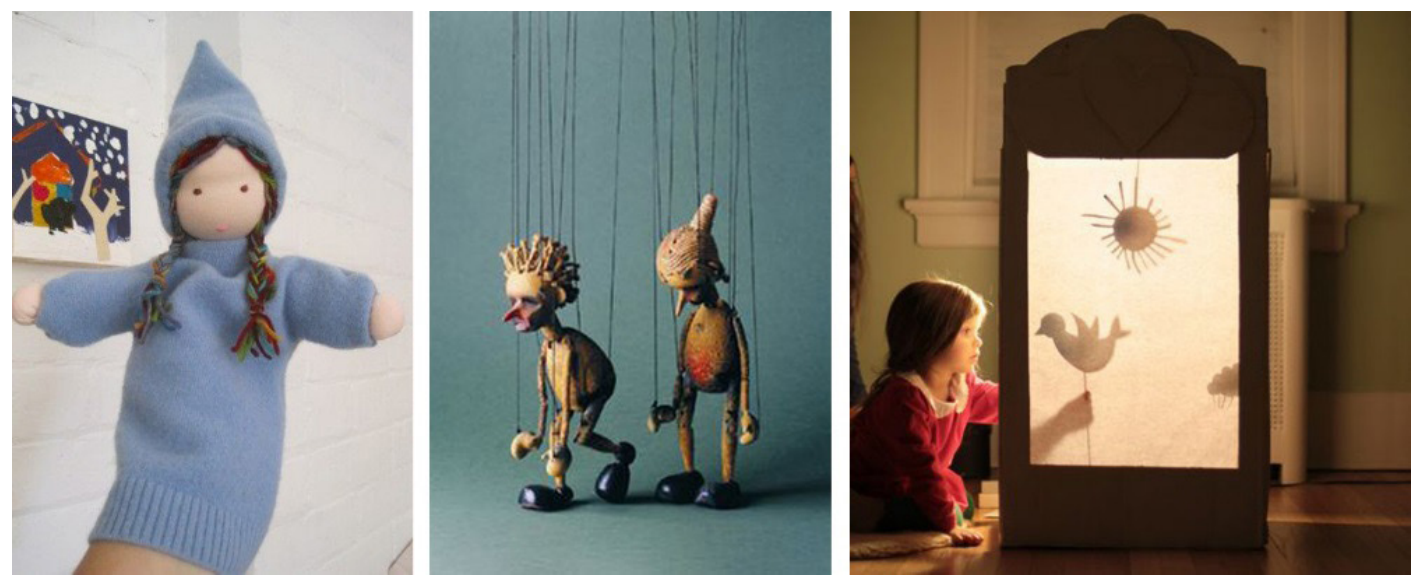

Fig. (8) Glove, Marionette, \& Shadow Puppets ${ }^{20}$

\subsection{Puppets in Museums:}

\subsubsection{Puppets in "Münchner Stadtmuseum" - Germany.}

The Puppet Theater Collection was established in 1940 in the context of a proposed exhibition on southern German puppetry in Munich. It also encompasses complete bequests of puppet show booths, decorations and textbooks.

\footnotetext{
${ }^{19}$ The British Museum, “Collection Online: Paddle Doll,” Accessed September 2, 2017, http://www.britishmuseum.org/research/collection_online/ collection_object_details.aspx?objectId=1 18802\&partId=1

${ }^{20}$ Lamya Adly, Photos from Münchner Stadtmuseum, August 10, 2016.
} 


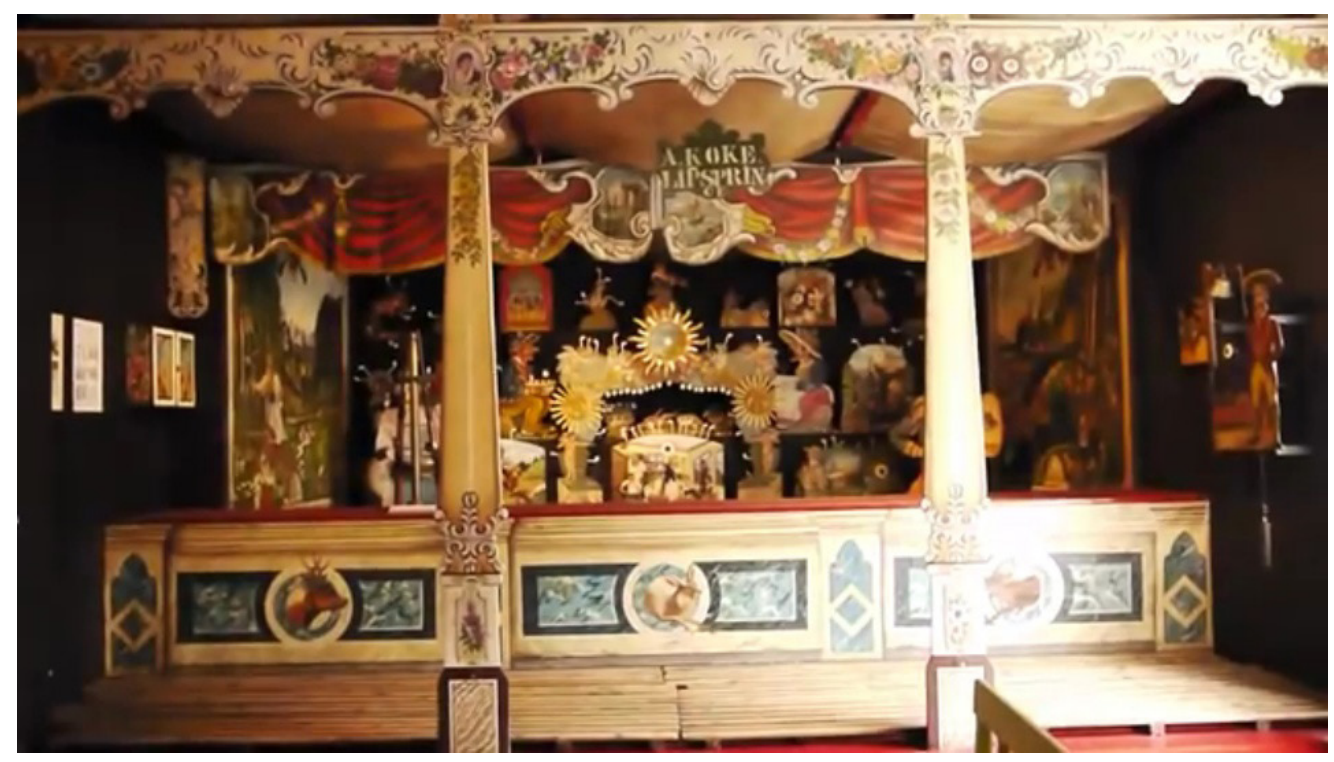

Fig. (9) A vintage puppet theatre from Münchner Stadtmuseum ${ }^{21}$

\subsubsection{Using Puppets in Creating Uncommon Experiences:}

In 2015, the REM museum in Germany had a very interesting exhibition that aimed at making the visitors discover the worlds' history. This exhibition used the popular puppet of Walt Disney's "Donald Duck" in interpreting some of the most famous artworks in the world in a unique way.

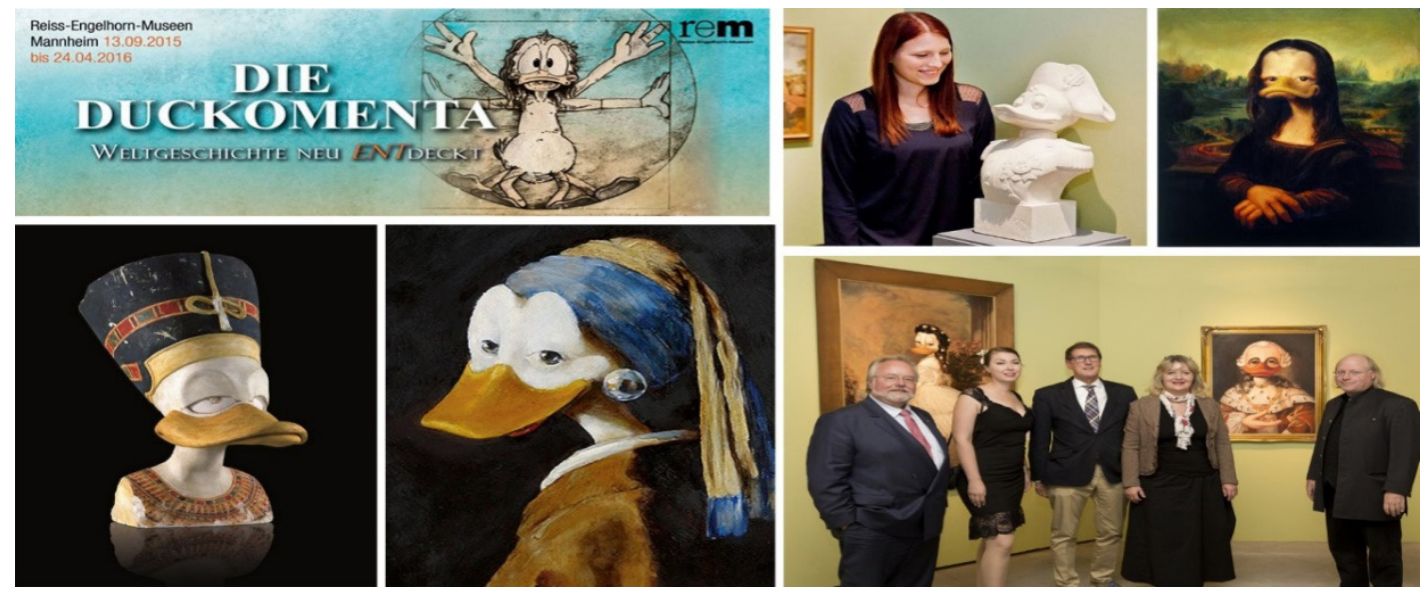

Fig. (10) The popular Disney character "Donald Duck" in REM museum. ${ }^{22}$

\footnotetext{
${ }^{21}$ ibid

${ }^{22}$ Ghada Hammoud, “Marketing Tips for Museums”, Interview, Faculty of Tourism \& Hotel management, December 2016.
} 


\subsubsection{Nubia Museum}

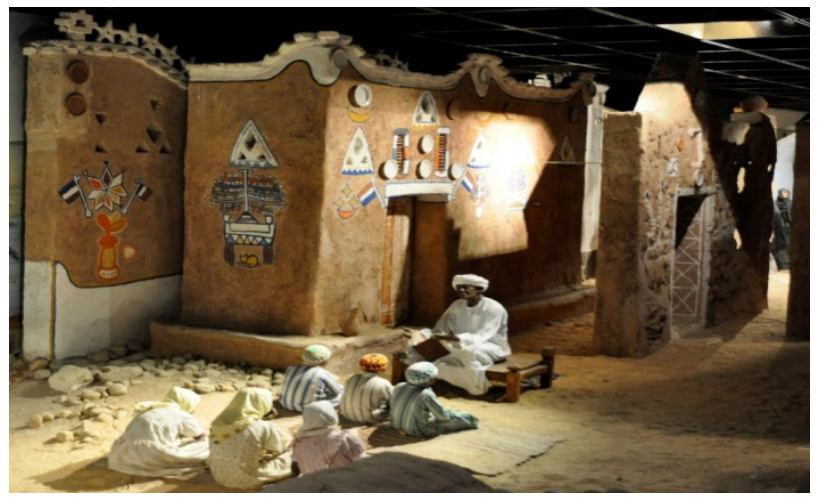

Fig. (11) Wax Human Figure Puppets telling the story of "Al Kuttab"; the rural traditional school.

\subsubsection{Agricultural Museum}

The Agricultural museum in Cairo has a great collection of wax-puppets that are meant to simulate human beings to tell stories of a craft, traditions and celebrations, or reflect scenes from the daily life.

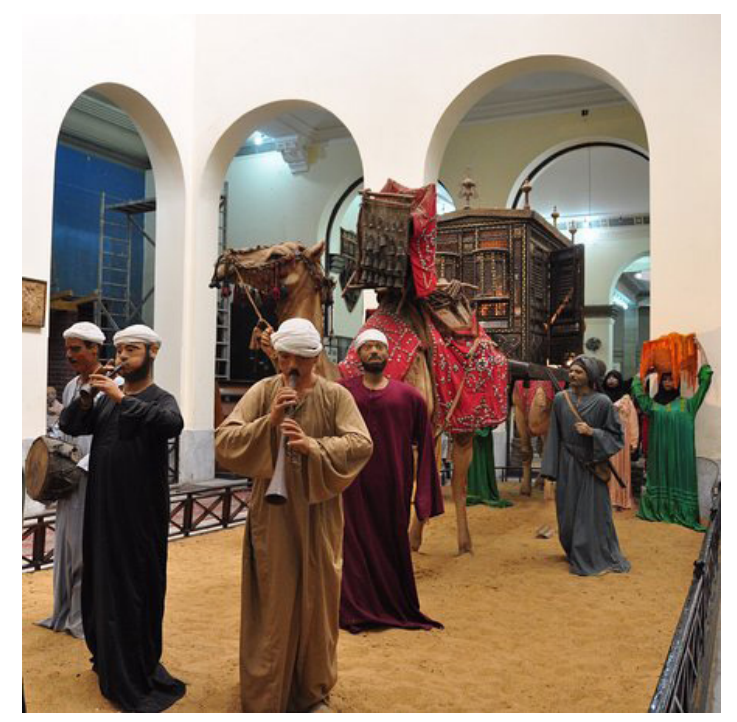

Fig.(12) Wax Puppets in the Agricultural museum in Cairo.

One of the most interesting collections of puppets is that of King Farouk, who received a collection of about 375 puppets, as gifts from different countries. They are stored in Kasr AL-Jawhara museum, at the citadel of Saladin, in Cairo. ${ }^{23}$

Other examples can be seen at different museums, like that of the Ethnographic museum, the Nile musem, Helwan's Wax museum, etc.

${ }^{23}$ Nabila Hassanein: Director of Qasr El-Jawhara Museum, Interview by Nermine Moustafa, June 19, 2017. 


\subsection{Experience Design \& Cultural influence:}

The particular type of experience that a visitor reports anticipating or enjoying depends on the individual, the visit, and what the museums offer. Visitors tend to avoid some museums on the basis of generalized perceptions about the types of experiences available inside them. Even if museums offered more varied experiences, the challenge would be breaking through the visitor's mental scenario for visiting a specific museum ${ }^{24}$.

Museum exhibitions have been likened to a play: an exhibition has an overarching theme or storyline that can be divided into acts (galleries) and scenes (display clusters). Individual elements such as text panels, images and objects can in turn be related to dialogues, soliloquies and props. ${ }^{25}$

Scenography demonstrates the potential to see the exhibition environment as a holistic visual creation. The environment both reflects and reinforces the intended narrative through the selections of colour, light and form. ${ }^{26}$

Atmospherics offers a framework for characterising the influence that designed visual cues can have on visitor behaviour. Visitors use these as they seek out environments that best fit their needs, interests and goals. $^{27}$

\subsubsection{Experience Design \& cultural aspects:}

The main aim of a museum is to communicate its heritage and to make its visitors enjoy the pieces through the museographical resources, the building, the interior design, the light and the colour. The light as well as the colour and the materials are used to emphasize the concepts and influence in the mood, creating a global experience. On the other hand, the museum applies a countless number of museographical resources (scenographies, tactile screens, avant-garde technologies, audible resources, audiovisuals, construction games, writing rooms, etc.), that help to understand concrete aspects such as religion, habits, writing and politics. ${ }^{28}$

If audiences are not comfortable, and do not have a cultural connection, then the chances for an engaged and active visit are greatly reduced. Museums aim to create designed spaces that people choose to come to. "Where displays are easy for people to relate to, local and repeat visitors will increase. Where the experience of the...museum is comfortable, enjoyable and personally extending, people will seek it out". ${ }^{29}$

Proxemics, chronemics, and colour are along with several other aspects of non-verbal and crosscultural communication- including visualism. ${ }^{30}$

Proxemics: Is the use and understanding of space as an aspect of culture that has been used to analyze (theoretically and empirically) behavior between people in different cultures and how this occurs in specificspaces. ${ }^{31}$

Chronemics: is the understanding of time as a component of culture. Cultural communication research on understandings of time, referred to as chronemics, would not appear at first to offer insights into museum display. Both the understandings of time and of time perspectives (past, present,

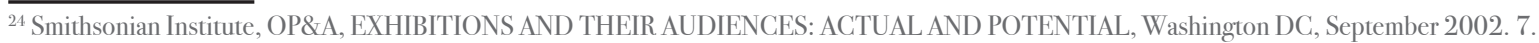

${ }^{25}$ Regan Forrest, «Design Factors in the Museum Visitor Experience» (PhD diss., Australia, The University of Queensland, 2014), 17-19.

${ }^{26}$ ibid

27 “Regan Forrest, Design Factors in the Museum Visitor Experience, The University of Queenslan, Australia, 2014, P59)

${ }^{28}$ Marta Teres, "Museums, spaces and museographical resources. Current state and proposals for a multidisciplinary framework to open new perspectives," Spain, University of Barcelona, 2015.

${ }^{29}$ Hooper-Greenhill, The Educational Role in Museums, London: Routledge, 1999, 256.

${ }^{30}$ Pamela Erskine-Loftus, Disrupting Design: The Impact of Cultural Contexts, Exhibitionist, Spring 2014, 13.

31 ibid, 14 .
} 
future orientations) are culturally connected. ${ }^{32}$

Colour: The greatest research on culture and colour has been conducted within branding and brand marketing and the use of multiple colours as an attempt at diverse appeal ${ }^{33}$

\subsection{Storytelling in Museums:}

\subsubsection{Types of Stories:}

- Fiction: Non-factual descriptions based upon the imaginations of the author

In museums: Fable, fairy tales, folklore, historical fiction, legend, mythology and science fiction

- Non-fiction: Factual description of real things.

In museums: Biography/autobiography, narrative nonfiction, textbook

\subsubsection{Why Storytelling in Museums?}

Museums are all about stories! Objects have many stories to tell and can be used as anchors and triggers for a huge range of stories, both factual and fictional.

Museums are places of learning associated with the presentation of facts. Storytelling is a great medium for making sense of objects. Stories afford deeper understanding of an object's function and meaning. Telling stories can enable us to draw links between past, present and future, bringing to life the human presence behind any object. ${ }^{34}$

\subsection{Celebrities \& Puppets:}

There were many Egyptian celebrities who were known for their love of puppets, like the monologist, Mahmoud shokouku, whose story with puppets is very inspiring:

Mahmoud Shokouku, was born in Cairo, in 1912. He was the founder of the Egyptian Puppet Theatre. He introduced the popular puppet "Aragoz" to theatres. He used to make his own puppets from wood, depending on the skills that he had due to his previous carpentry experience. The most famous puppet shows that he performed were "Al Sindbad Al-Balady" \& "The Count of Monte Shokouku". ${ }^{35}$

\footnotetext{
32 ibid

${ }^{33}$ Pamela Erskine-Loftus, Disrupting Design: The Impact of Cultural Contexts, Exhibitionist, Spring 2014, 15

${ }^{34}$ The British Museum, “Fieldnotes Storytelling,” Accessed February 20, 2017, http://www.britishmuseum.org/PDF/storytelling_resource_ changed_font_size.pdf

${ }^{35}$ Sanaa El-Bissy, "Shokouku Al-Sindbad Al-balady" (Shokouku The Local Sindbad), Al-Ahram Newspaper, June 7, 2008. http://www.ahram.org.eg/ Archive $/ 2008 / 6 / 7 /$ Writ 1.htm
} 


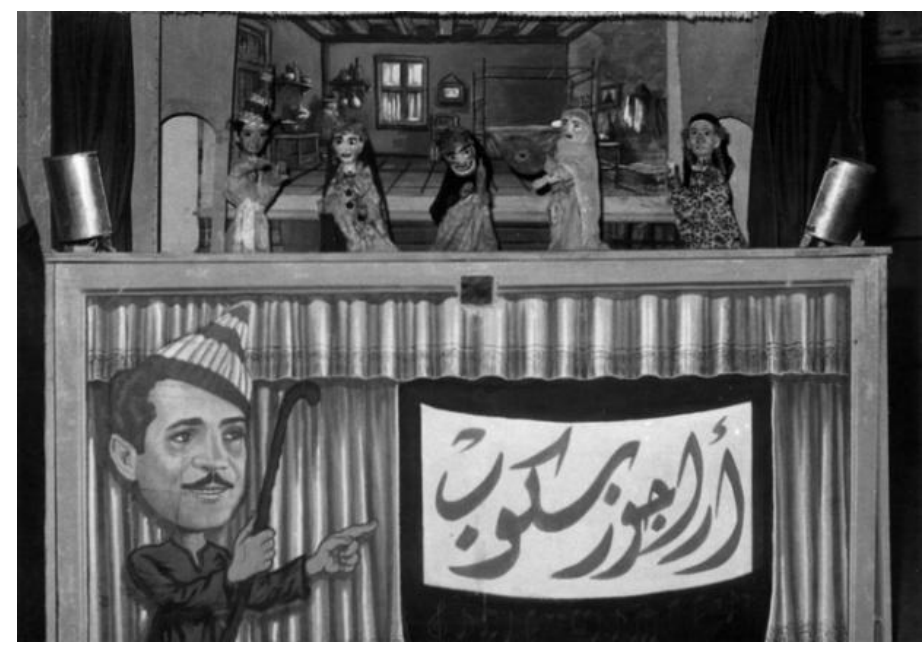

Fig.(13) Shokouku's Puppet Theatre as featured in one of his old shows.

He is the one and only Egyptian artist who has a puppet that simulates his unique character and style; wearing his famous costume "Gilbab Balady", wooden stick, and the special hat that he used to wear. He used this puppet to share the joy and entertainment in each and every part of Egypt where he started travelling from a city to another, to spread the happiness in the hearts of millions of his fans, and for the revival of the Aragoz theatre once again. ${ }^{36}$

Shokouku was admired by the Roman ambassador during one of his shows, that he offered him a grant to Romania to learn the fundamentals of this art. ${ }^{37}$
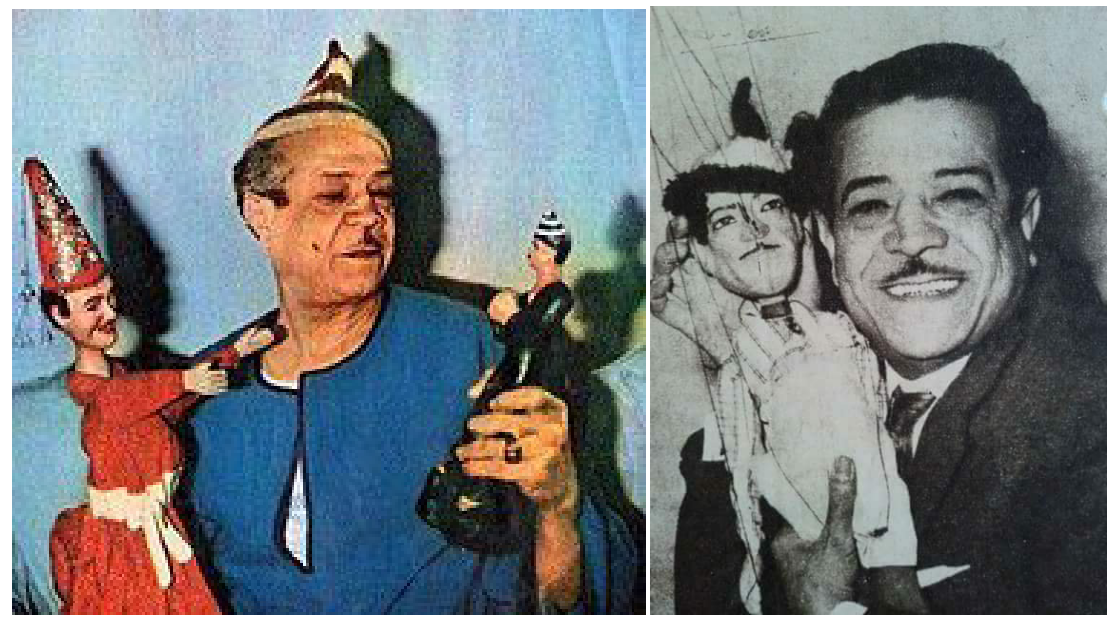

Fig. (14) Shokouku with his famous Aragoz \& his look-alike puppet ${ }^{38}$

Fig.(15) Shokouku with his Marionette look-alike puppet.

The Shokouku look-alike-puppet was not just for entertainment, but also for popular resistance against

\footnotetext{
${ }^{36}$ Alaa Mahgoub, "Shokouku.. min Alnijara wa Ihya2 Al-Afrah Ila Al-Cinema” (Shokouku.. from carpentry \& wedding shows to Cinema), Al-Ahram Newspaper, February $21,2017$.

${ }^{37}$ Hassan Magdy, "Fi Zekrah El-103, Wojuh Shokoku Albaeida a’an El-fan, Alnajar wal-munadhel wal-Aragoz” (In his 103rd remembrance.. Shokouku’s faces away from art.. the Carpenter, the fighter and Karagoz), Alyom Al Sabe’e Newspaper, May 4, 2015.

${ }^{38}$ Unknown Author, "Shokouku with his famous Aragoz and his look-alike puppet”, Wikipedia, Accessed February 17, 2017 https://ar.wikipedia.org/ wiki/Mahmoud_Shokoko

39 Wejjdann, "Shkouku with his marionette look-alike puppet”, Twitter, February 16, 2017, https://twitter.com/wejjdann1/ status/824057576023265280
} 
the British occupation; where the people who worked in the popular resistance used to use the bottles in manufacturing Molotov bombs, to be used as weapons against the occupation. The old-belongings' merchants used to provide them with these bottles. They depended on the popularity of Shokouku; where they travelled through the country saying the famous phrase "Shokouku for a Bottle - "شكوكو بـإزازة" as a call for exchanging the empty bottles with the beloved shokouku look-alike-puppet, finding a high enthusiasm from people everywhere to get it. ${ }^{40}$

\subsection{Field Study:}

This part of the research aims at measuring the influence that puppets and storytelling have on people, to use the results in deriving creative suggestions for designing new experiences for the Egyptian museums. A questionnaire was designed to get peoples' opinions and expectations. The field study also included interviewing people to allow them to express themselves openly, as some people don't like answering questions in a written format. The questions of the questionnaire and the interview were the same, to make the analysis stage easier and more accurate.

\subsection{Questionnaire Model:}

1. How old are you?

$(6-18),(19-30),(30-40),(40-50),(50-60),(60-70),(70-80),(80-90),(90-100)$, (Over 100)

2. What is your nationality?

3. What is your Profession?

4. Doyou like Puppets?

5. What Types of Puppets do you know?

6. Do you have a favorite puppet? Name it?

7. What type of puppets do you prefer?

8. Do you find a place that uses puppets in its setups attractive or not?

9. If you are invited to visit a place that you don't like, would you change your mind if you knew that it has a Puppet show?

10. Do you love visiting museums? Why? 
11. Do you still keep any of your childhood Puppets? Do you have a story to tell us about it? Do you mind attaching a photo of it?

12. What is the most interesting thing about Puppets?

13. Do you find Puppet-Making Interesting?

14. Do you Like Storytelling? Tell us what is the best thing that you like about it?

15. Do you find it interesting to be told a story by a Puppet?

16. Have you ever made a puppet by yourself? Do you keep it, or have a photo for it?

17. Would you like to learn to make your own Puppet?

18. Would you like to experience being a Puppet for one day?

19. Ifyou knew that there is a museum that integrates puppets, what do you expect to find when you visit it?

\subsection{Result Analysis:}

This questionnaire was distributed on a sample of 70 (based on the valid forms: 70 out of 100). The same questions were used to interview 30 more persons, to get the opinions of a random sample of 100 persons.

The Questionnaire included 20 questions, that aim at measuring the effect of puppets on people. It included both closedended, and open-ended questions. The result was as follows:

\subsubsection{Analysis of Close- Ended Questions:}

The Close- Ended questions aimed at collecting specific data of the studied sample. The following pie charts show the results of these questions in percentages. 


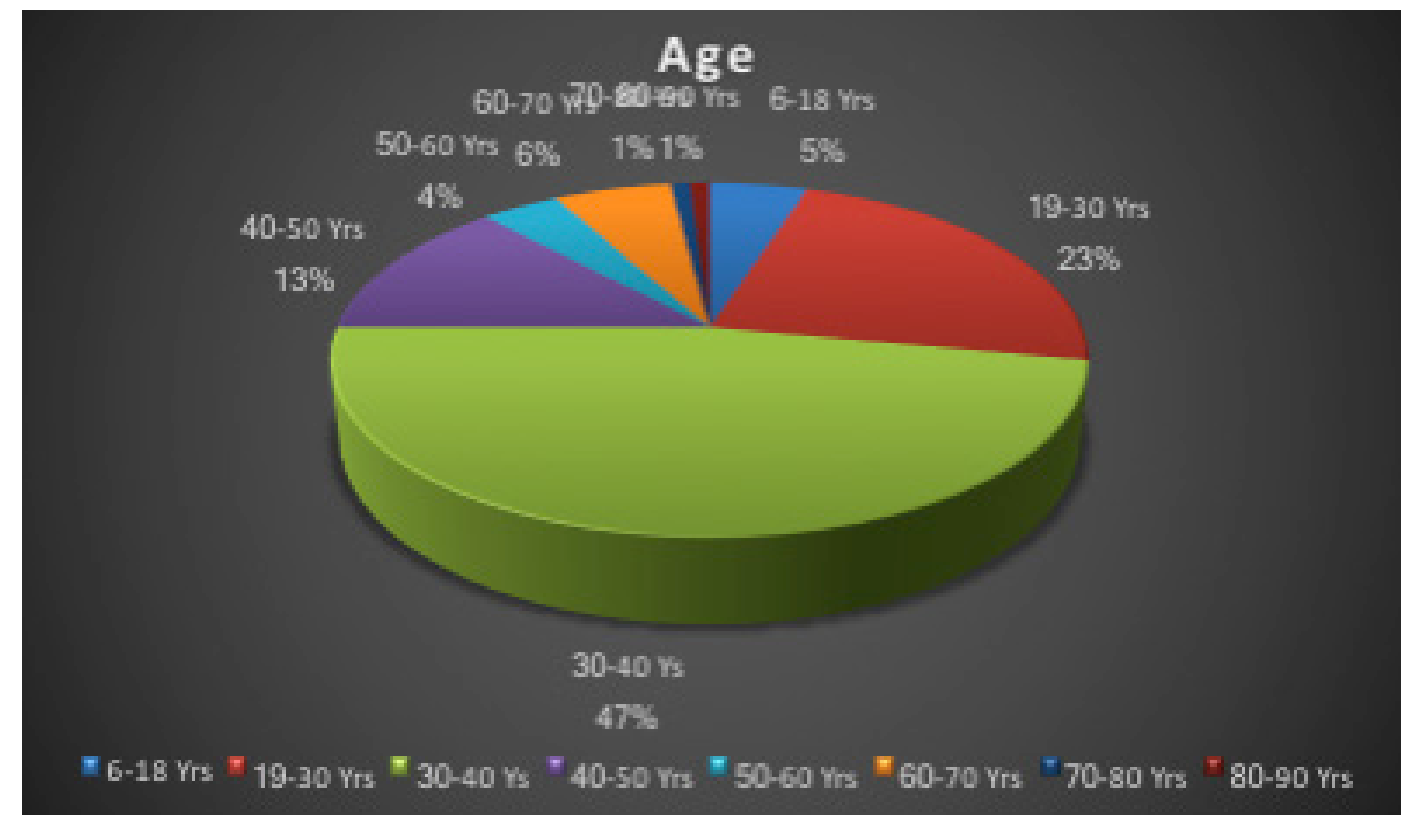

Fig. (16) Pie-Chart representing age

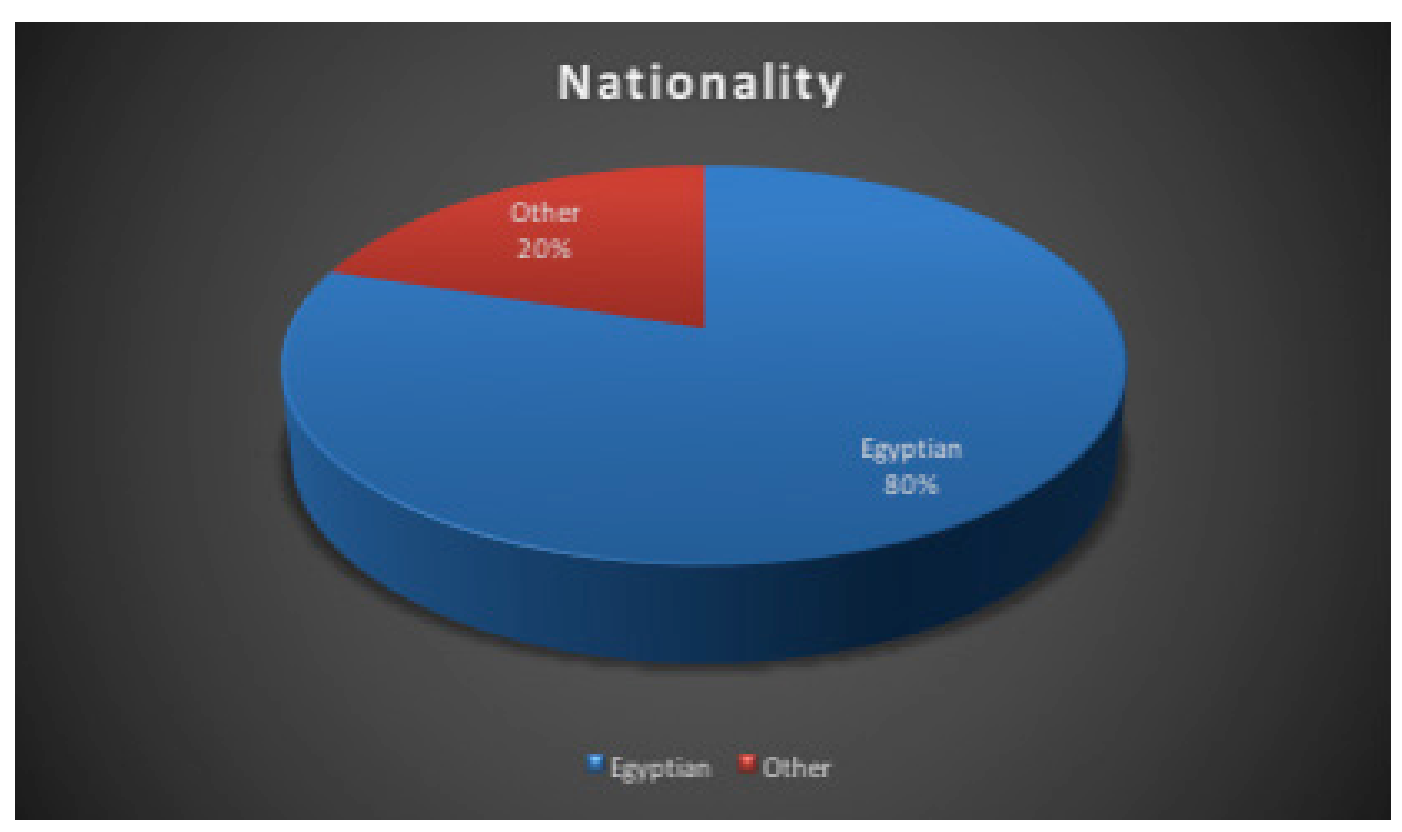




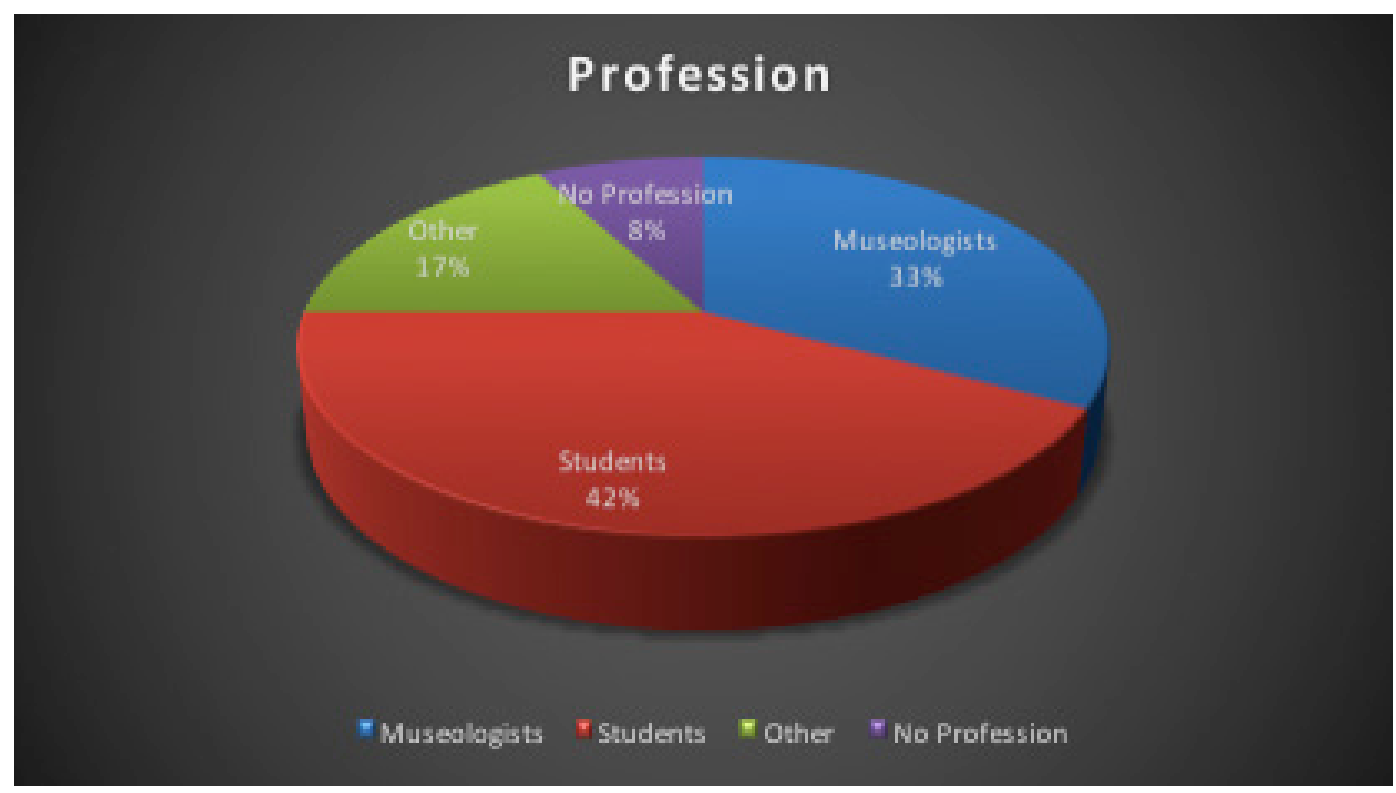

Fig. (18) Pie-Chart representing profession

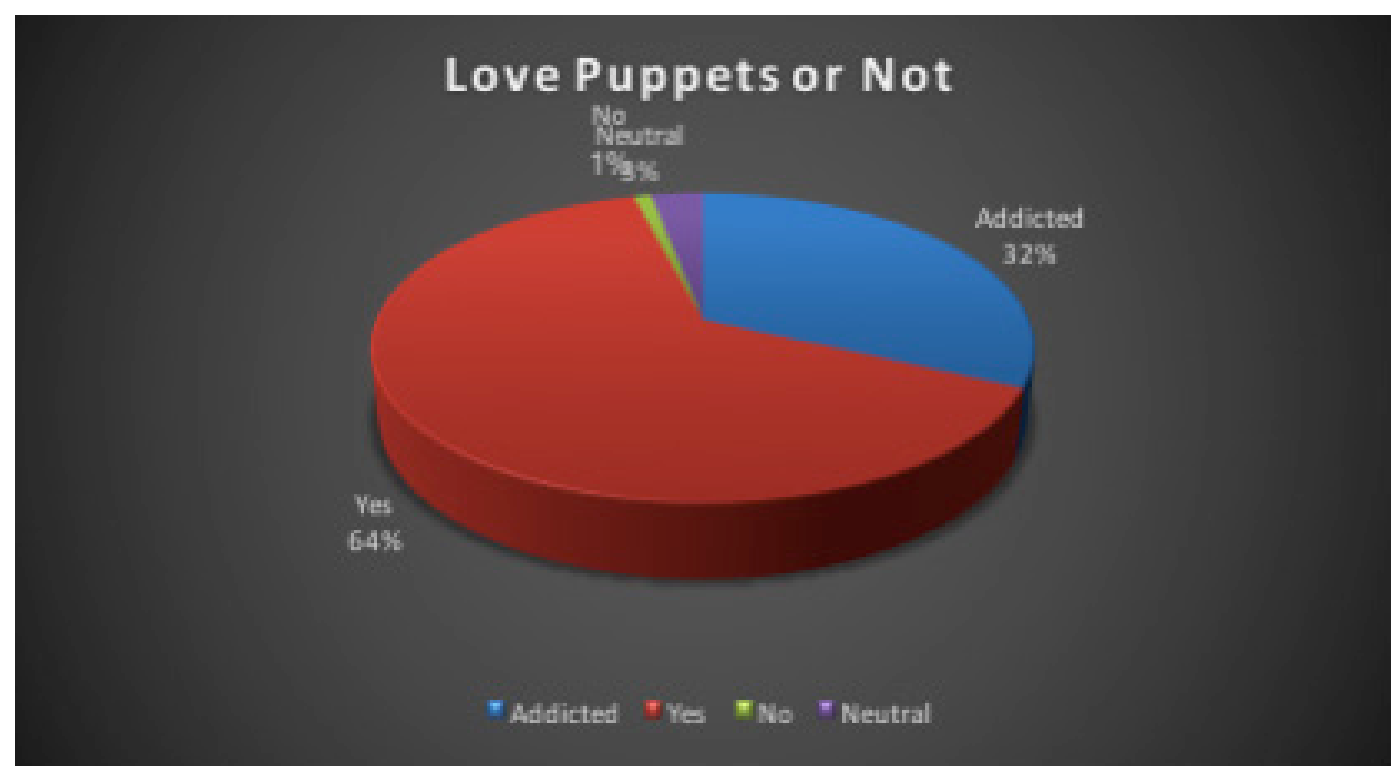

Fig. (19) Pie-Chart representing people who love Puppets 


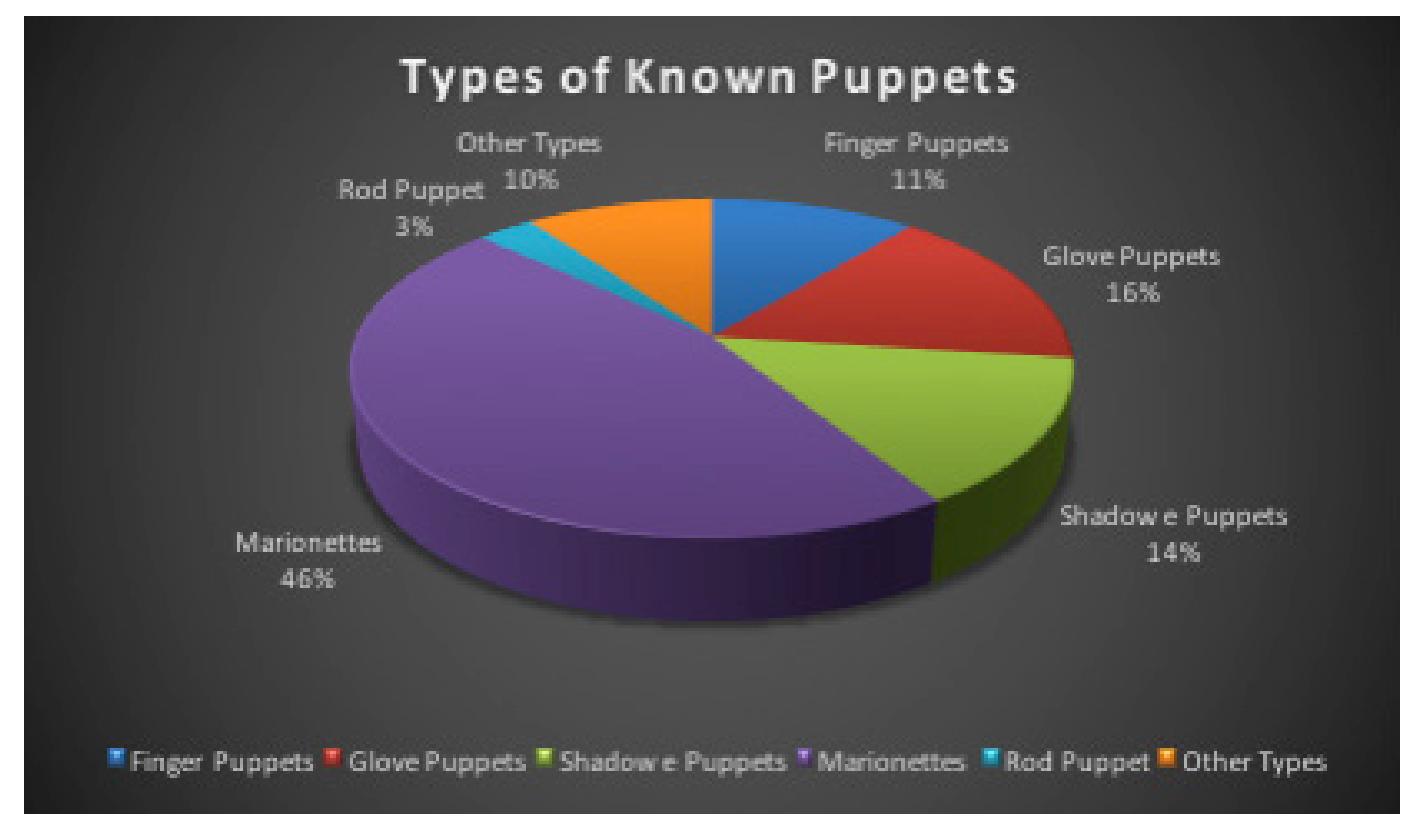

Fig. (20) Pie-Chart representing types of Known Puppets

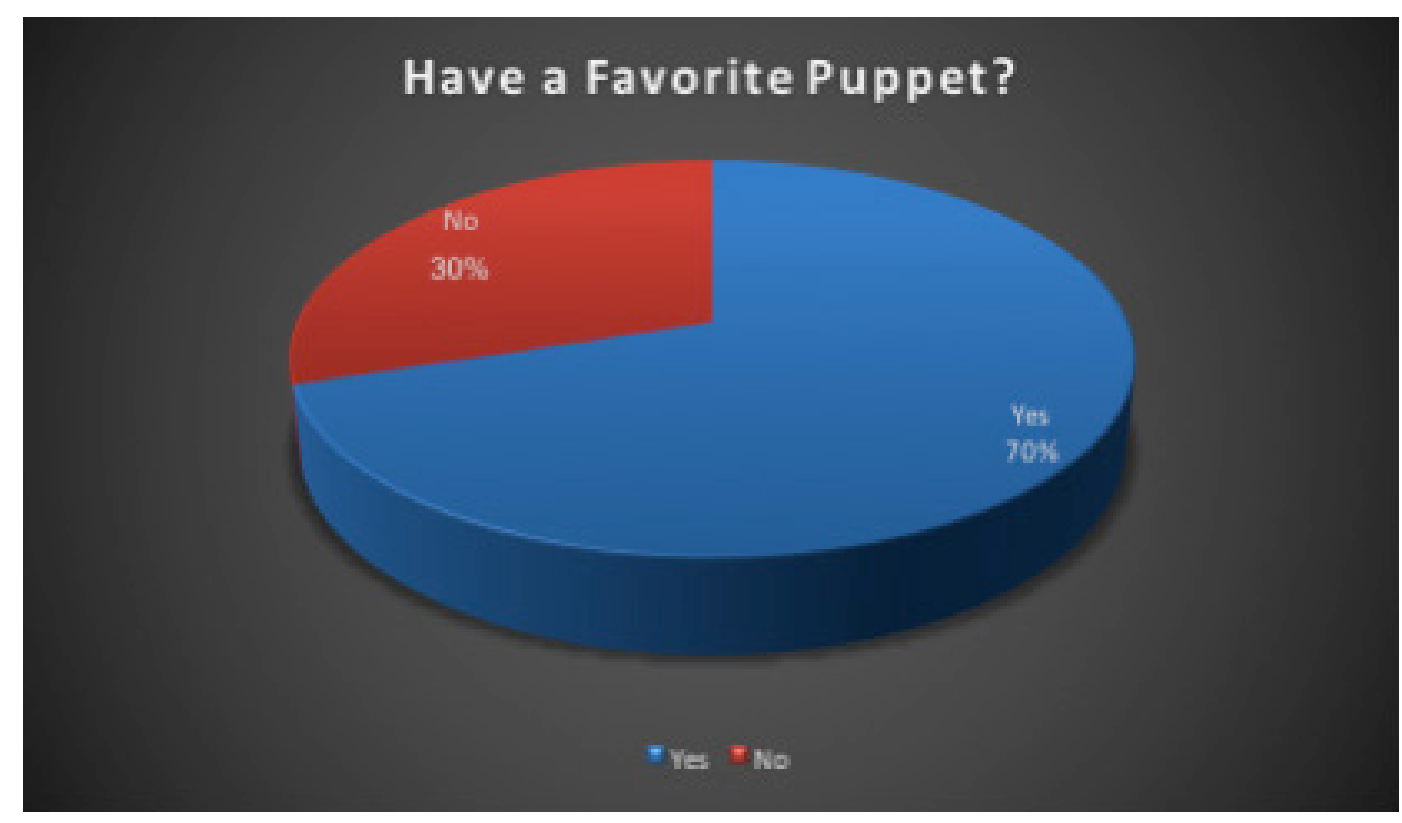

Fig. (21) Pie-Chart representing people who have a favorite puppet. 


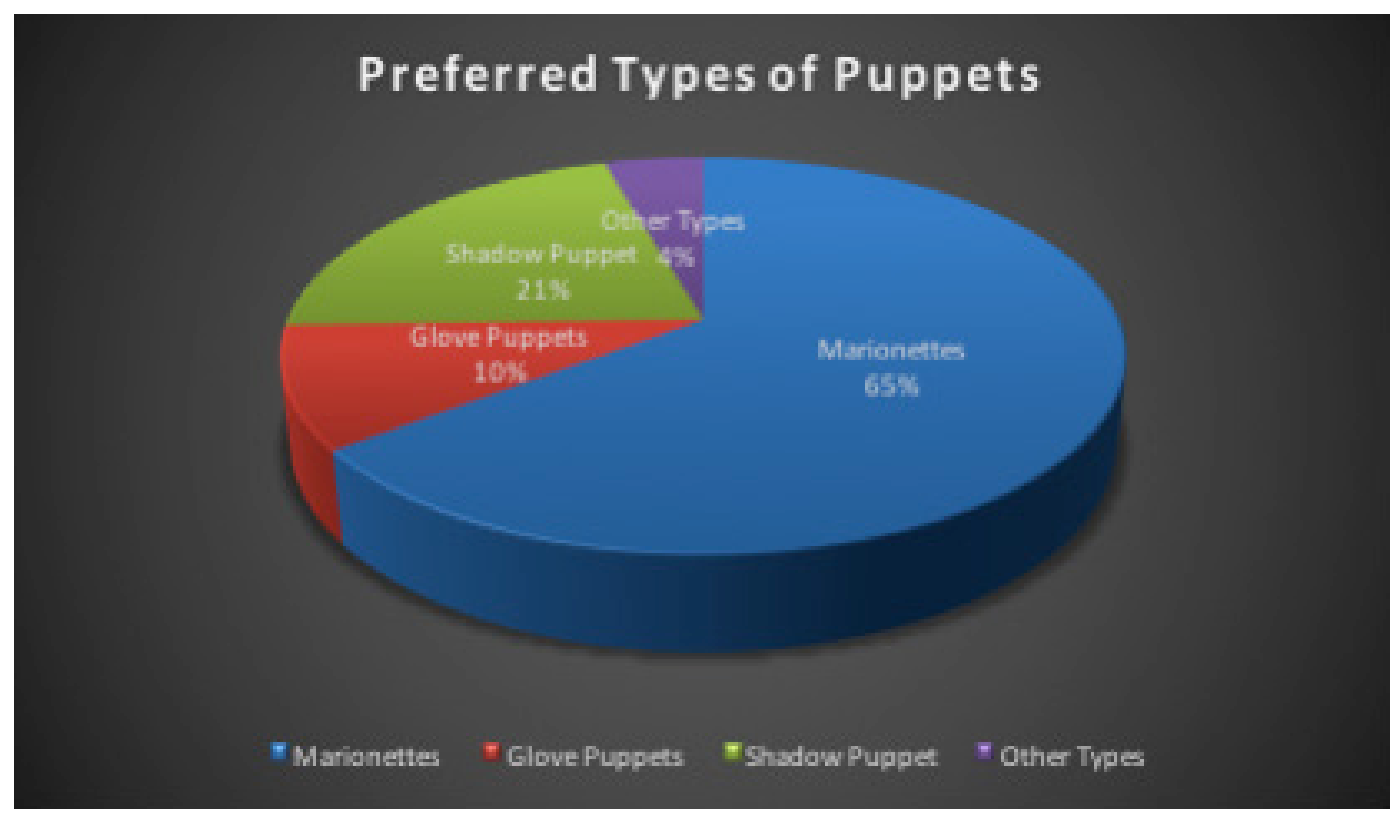

Fig. (22) Pie-Chart representing preferred types of puppets.

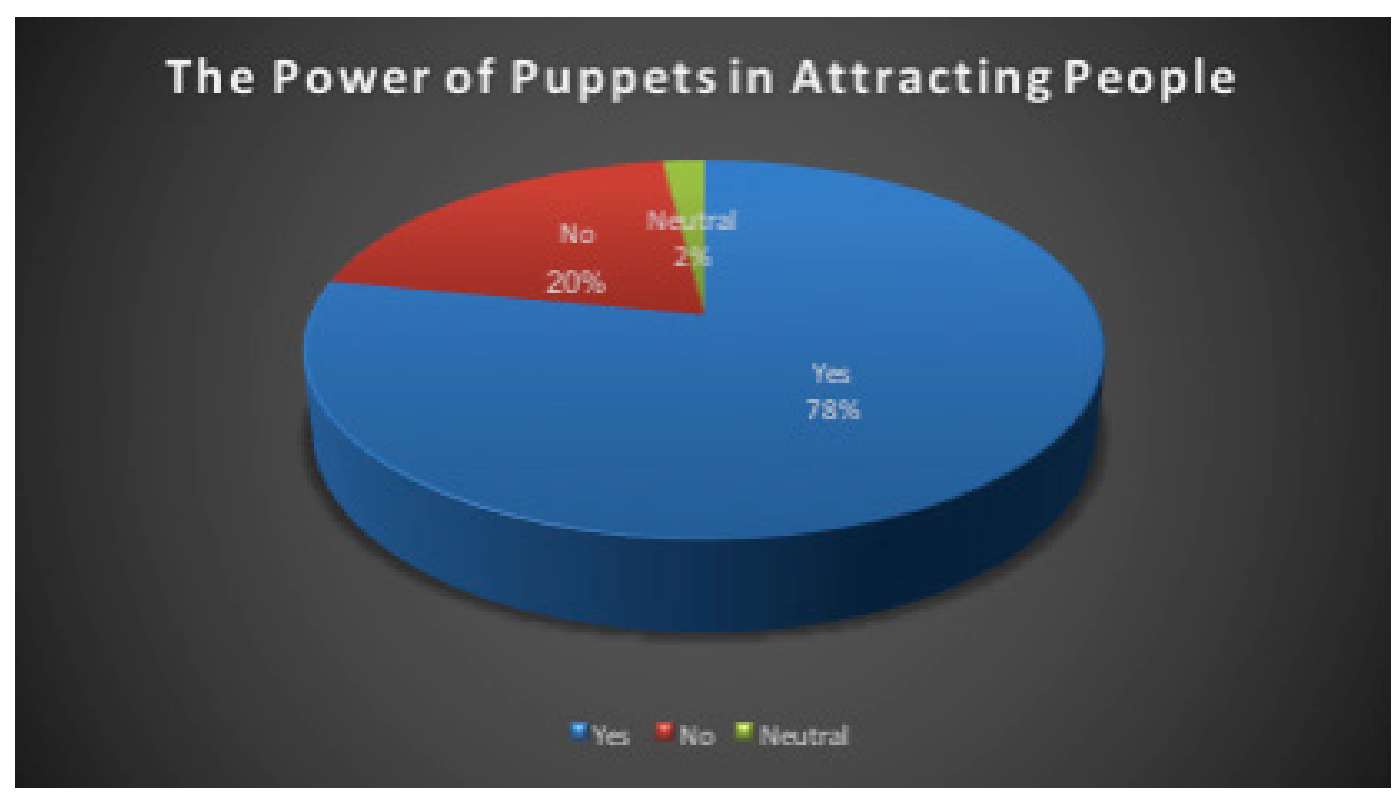

Fig. (23) Pie-Chart representing the to what extent do Puppets attract people. 


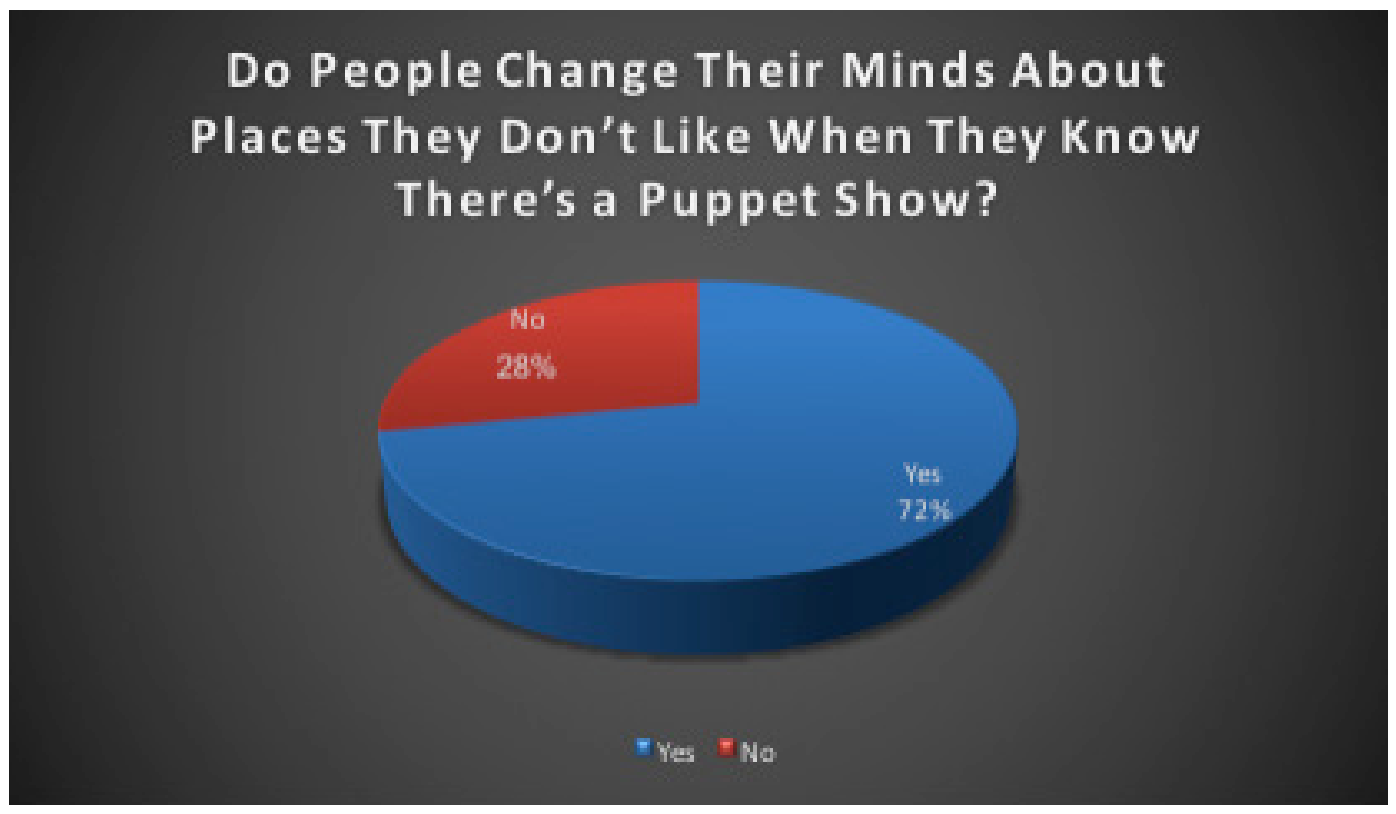

Fig. (24) Pie-Chart representing how puppets change people's opinions

\section{Do People Visit Museums?}

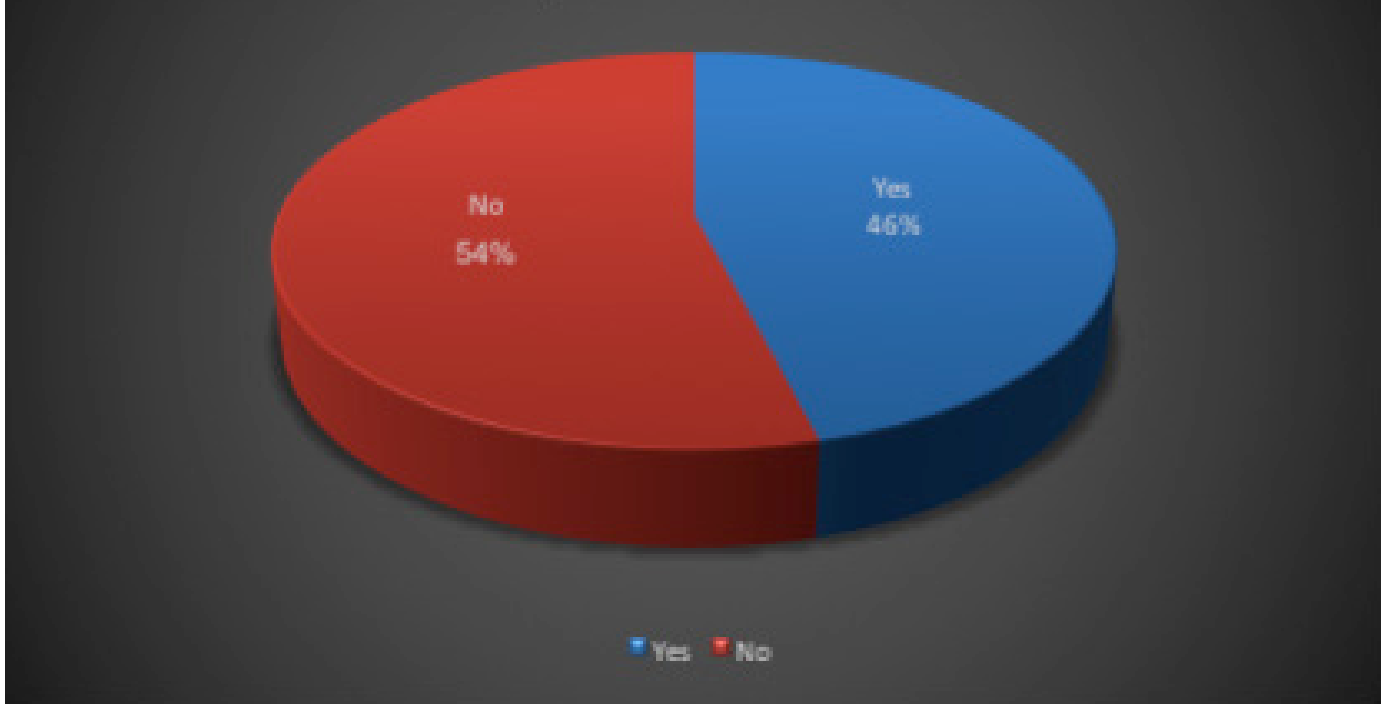

Fig.(25) Pie-Chart representing people who visit museums. 


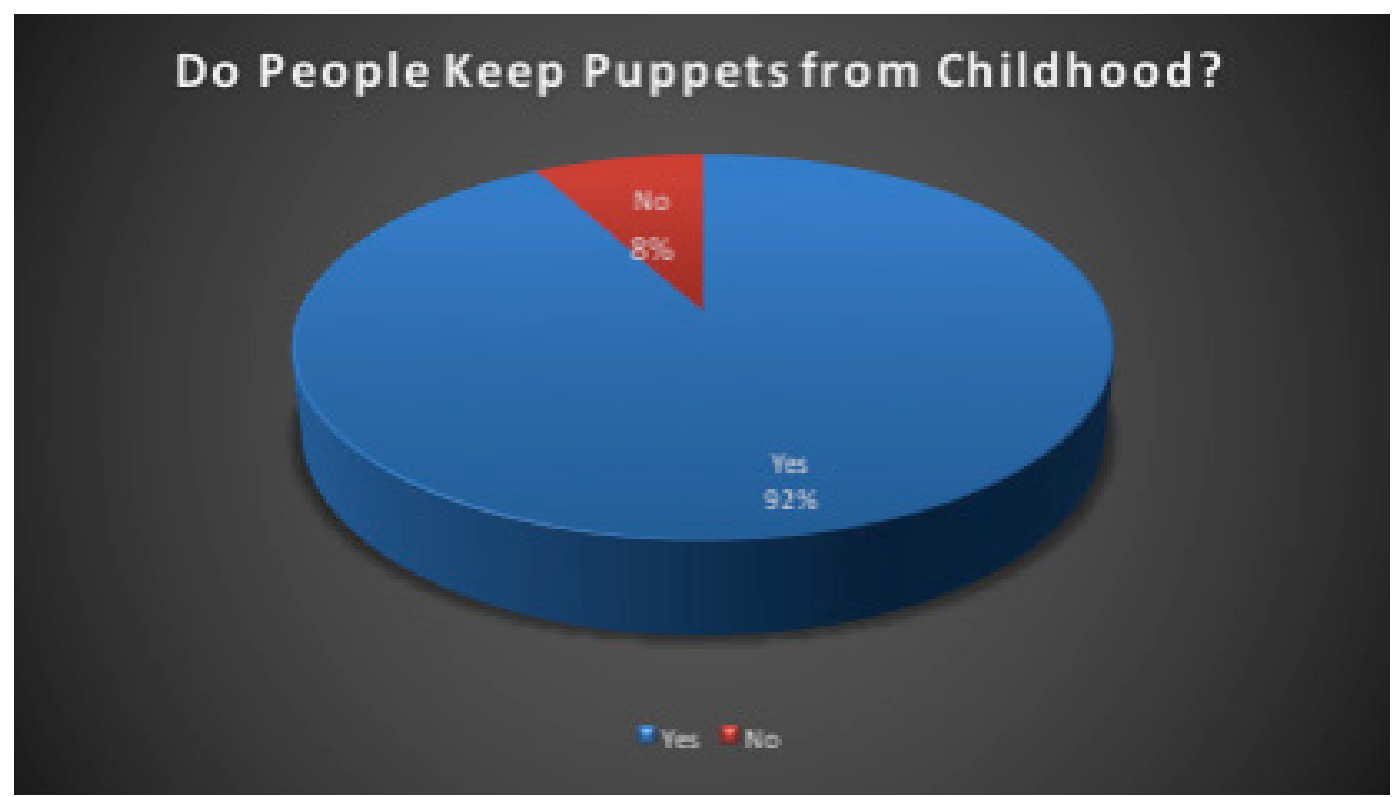

Fig. (26) Pie-Chart representing the results of Interviews \& questionnaires: People who keep puppets from their childhood.

\section{Are People Interested in Puppet making?}

No

$6 \%$

fes

9436

ryes $\mathrm{No}$

Fig.(27) Pie-Chart representing people who find Puppet-making interesting 


\section{Do People Love Storytelling}

$\mathrm{Na}$

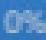

Yes

100 sis

ryes No

Fig. (28) Pie-Chart representing people who love Storytelling

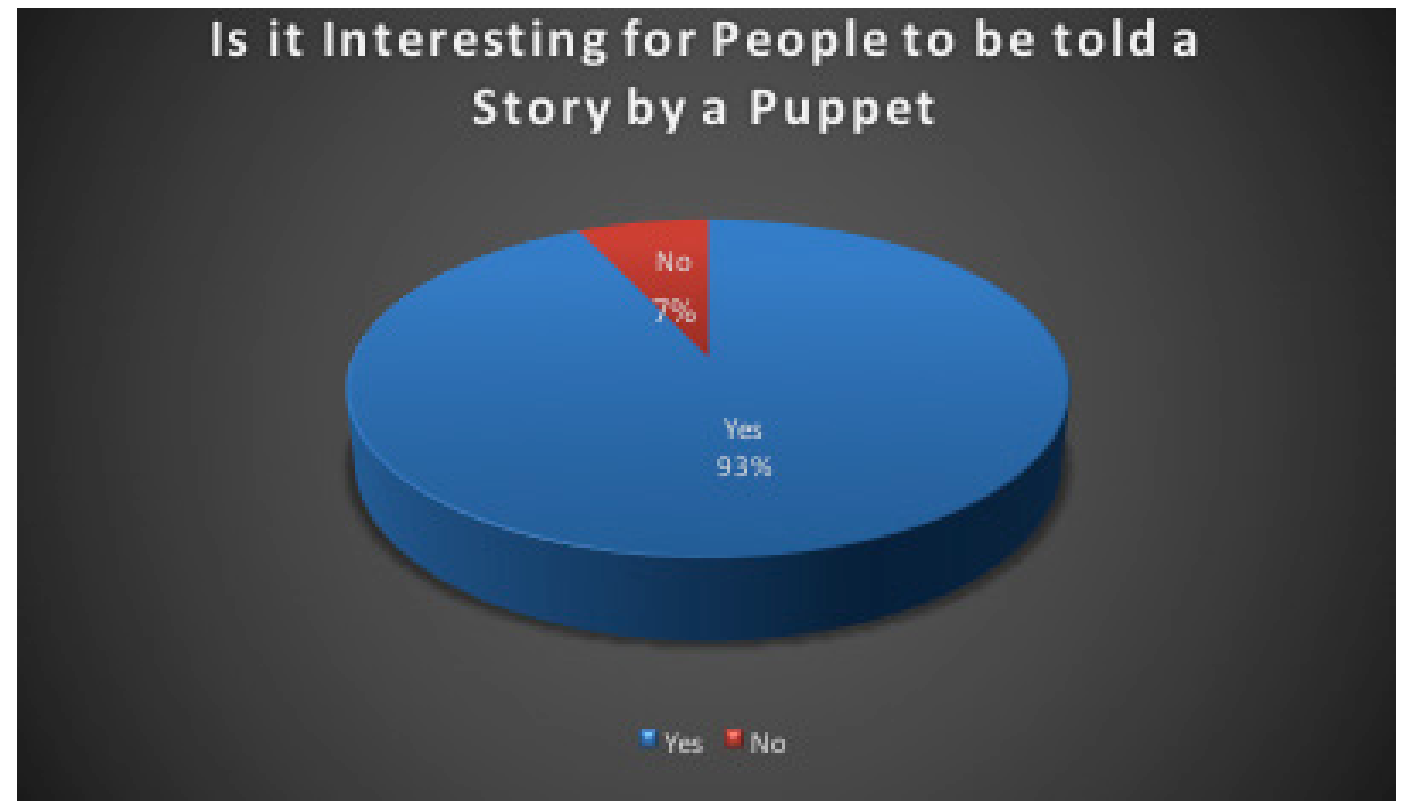

Fig. (29) Pie-Chart representing people who love to be told a story by a puppet. 


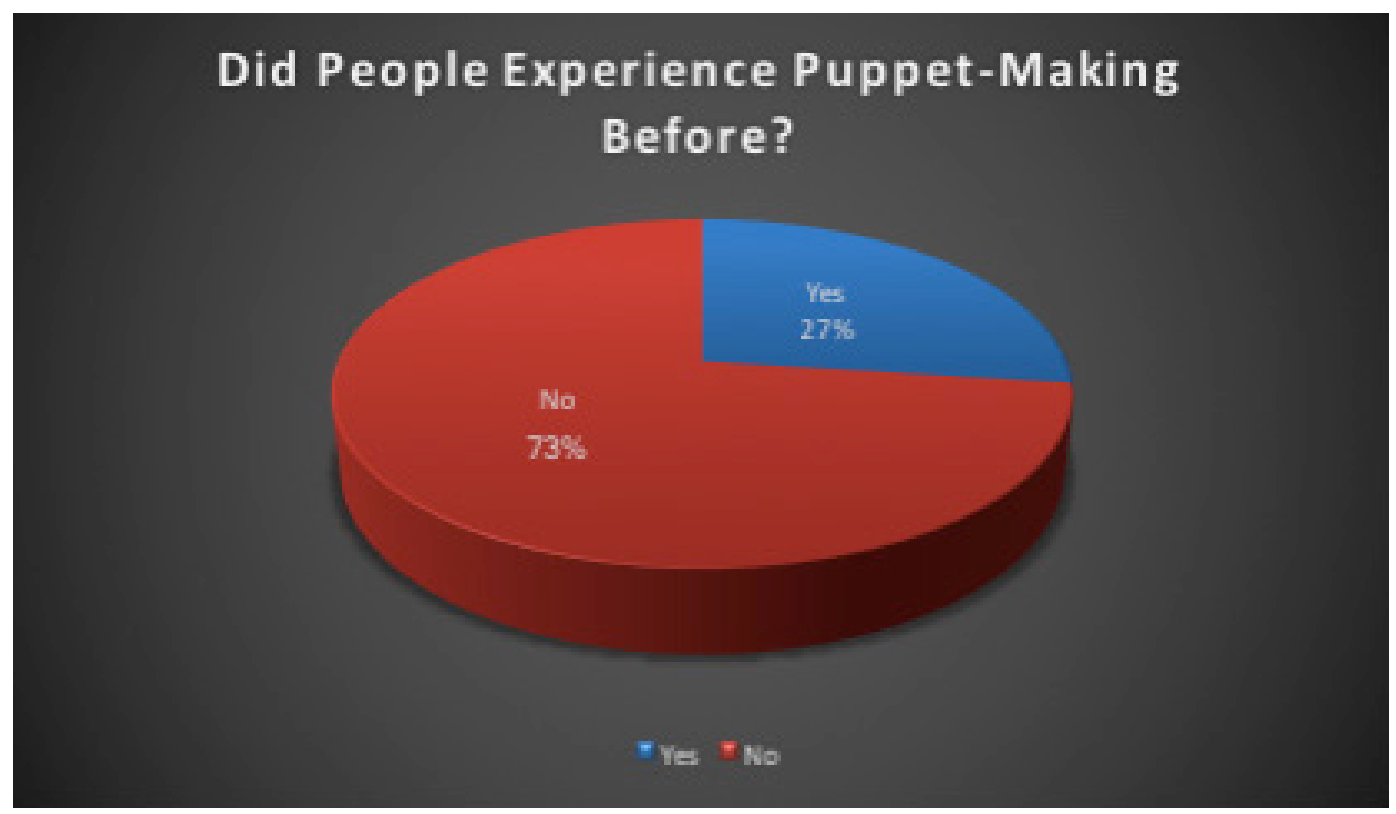

Fig. (30) Pie-Chart representing people who have previously experienced puppet-making.

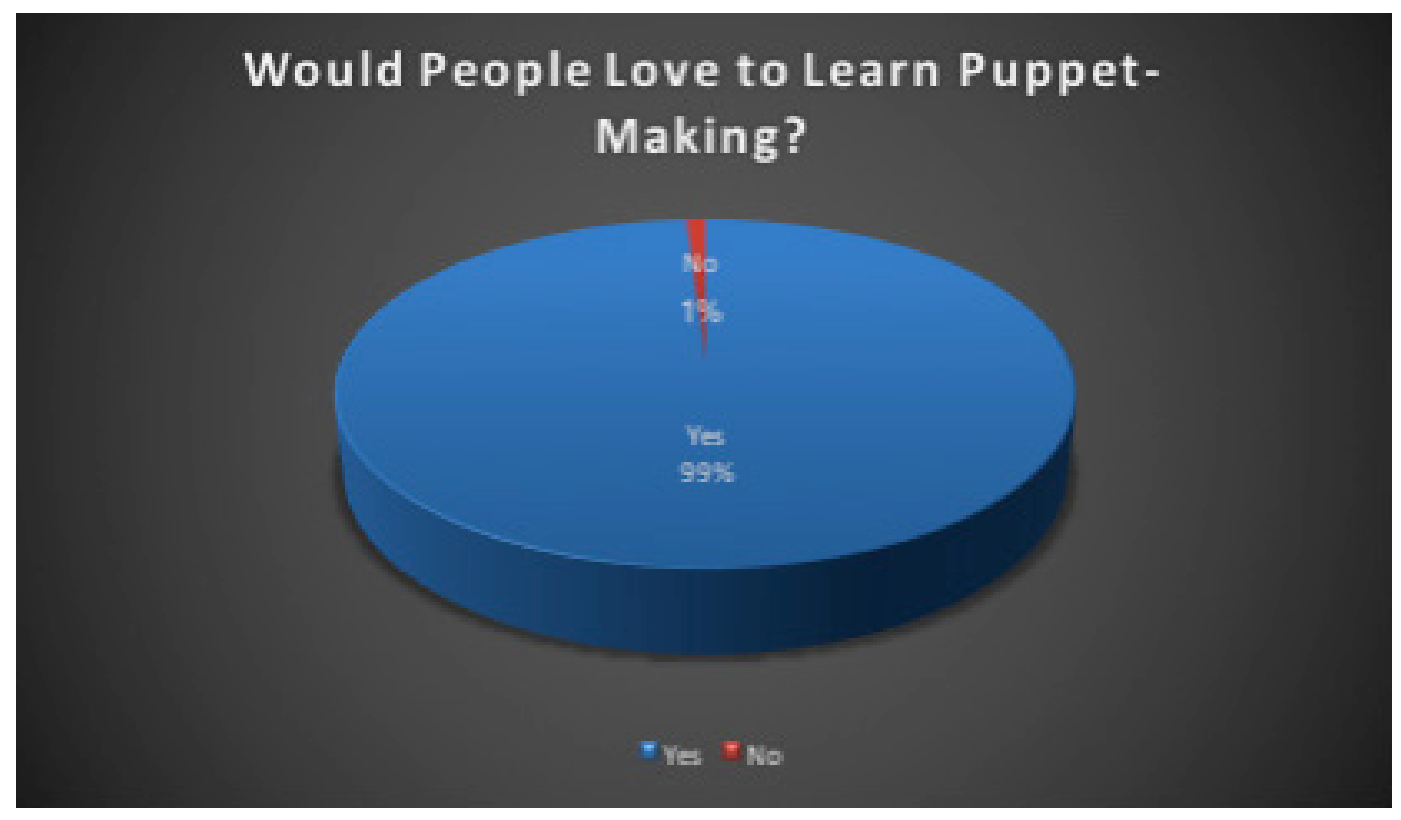

Fig. (31) Pie-Chart representing people who'd love to learn puppet-making. 


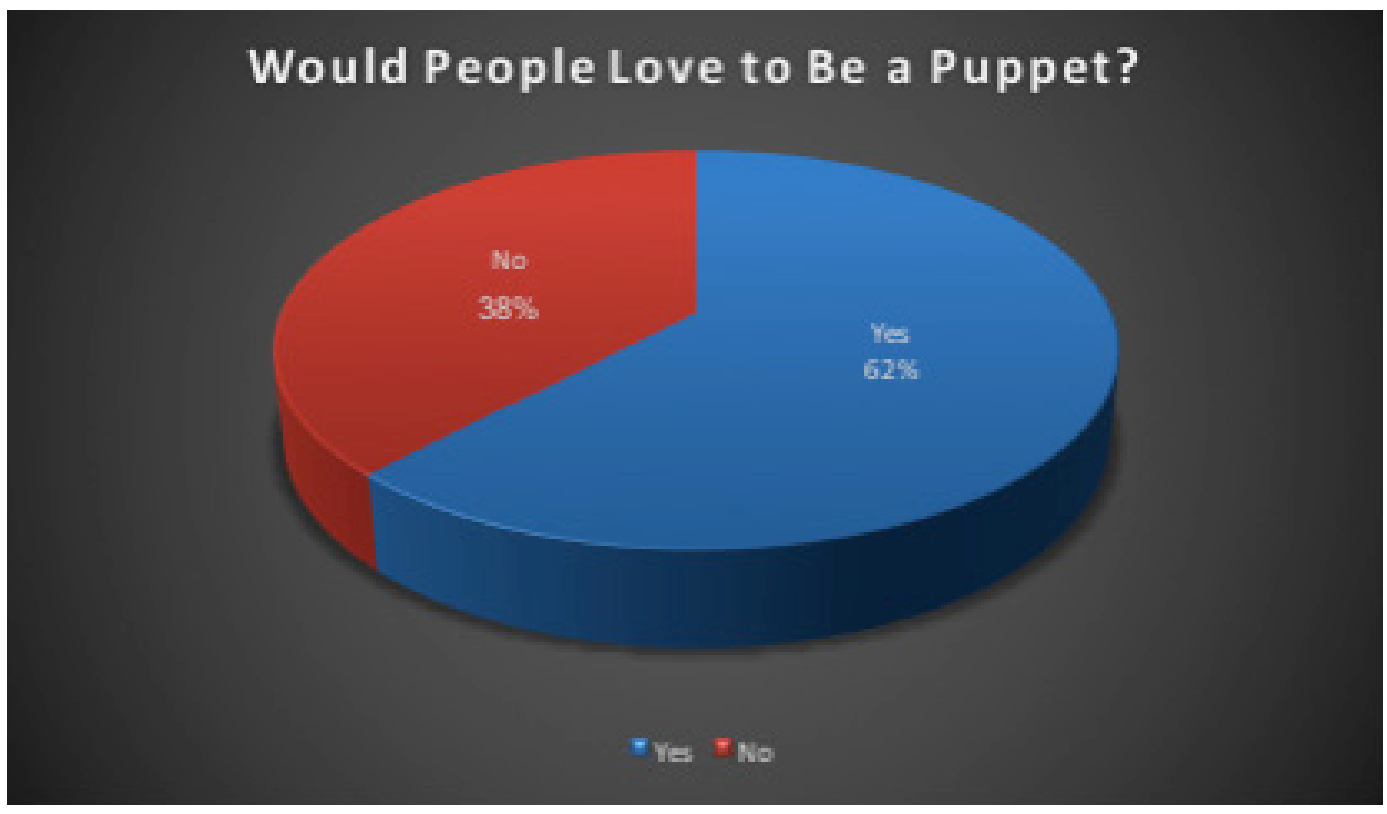

Fig. (32) Pie-Chart representing people who'd like to live the experience of being a puppet.

The answers show that most of the people with different ages, professions, nationalities and cultures love puppets and storytelling. $93 \%$ would live to be told a story by them and interact with the $73 \%$ of them experienced puppet-making before. $62 \%$ would love to live the experience of being a puppet.

\subsubsection{Analysis of Open-Ended Questions:}

The Open-Ended questions aimed at collecting specific data about the most interesting thing about puppets and storytelling. Most of the results show how people with different ages and cultures were influenced by puppets, especially the popular ones they used to have or watch in the television or theatre shows during their childhood. Most of the answers refer to replacing the curator by the doll, especially for kids' tours. Below are some of the most inspiring answers:

Rasha Elhawary, plastic artist, says that the type of puppets that she prefers the most is those made out of textile. Besides, she loves other types of puppets like "Koronba"; as it takes her back to childhood. The best thing that Rasha likes about storytelling is the suspense that makes her curious about the story. This makes her immersed in the story as if she is a part of it. Rasha wishes that museums introduce more details about puppets.

Sally Mostafa, museum curator, says that she prefers the socks puppets, as she used to collect the old socks and turn them into puppets. Regarding Storytelling, Sally added that she enjoys being moved by a story. She believes that Storytelling is what connects us to our past and to our future. Sally expects puppets to tell her historical stories related of the museum and its collection.

Nagwa Bakr, community engagement specialist, says that the most interesting type of puppets is the Karagoz. 

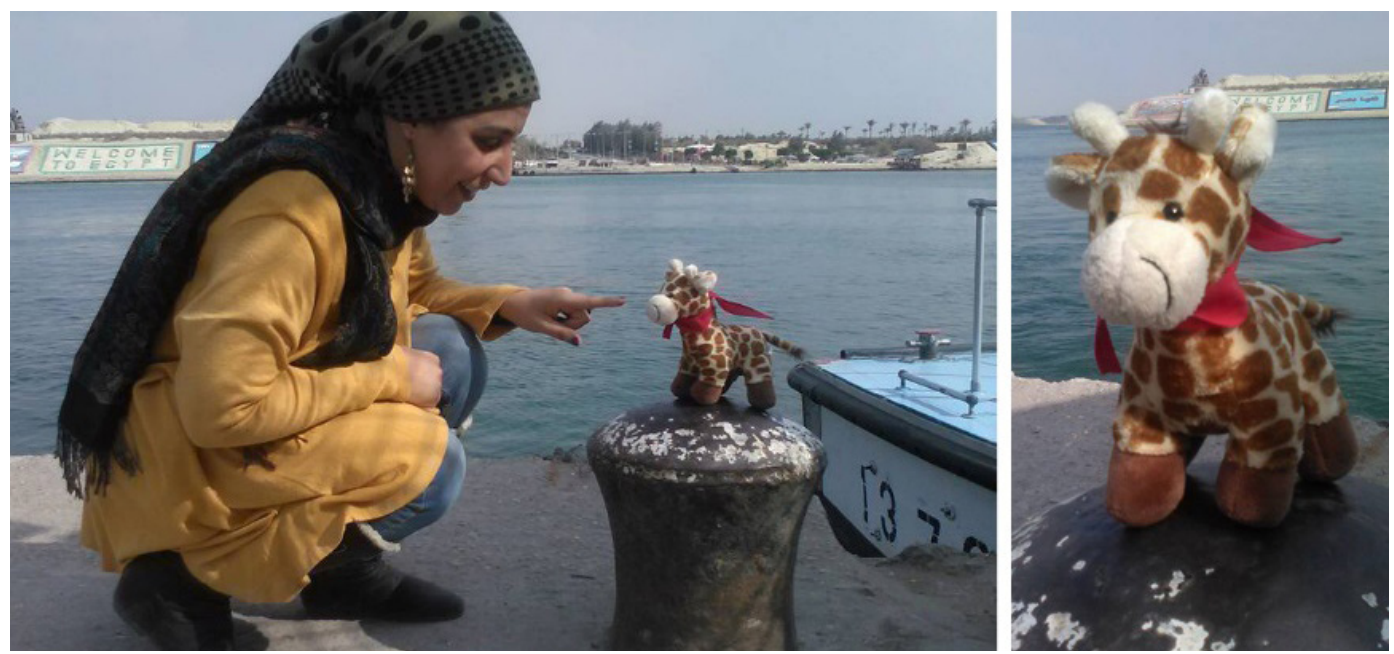

Fig. (33) Nagwa \& her Puppet Friend "Frederic" "1

Nagwa is fond of storytelling, especially when it links the past with the present. Nagwa expects to find a puppet that takes her in a guided tour instead of the curator.

Mr. Ihab Moussa, a 41 year-old information technology specialist, says that puppets are very inspiring to him since his childhood, especially the famous Egyptian puppet theatre show "El-Leila-EL-Kebira". Ihab thinks that a museum that integrates puppets will be showcasing models of old and popular puppets. It may be also using people who wear costumes of those puppets to tell stories and play with kids."

\subsection{Findings:}

1- Storytelling has the power to conjure up the magic of museums. It helps to explore the creative potential inherent in objects.

2- Storytelling has helped in transferring knowledge and experience from one generation to the other. It can pass on wealth of knowledge encompassed in our museums. It is a great medium for making sense of objects. Key storytelling techniques help break down the division between the expert delivering knowledge to a passive receptive audience through successful communication, which became an aid in learning of moral values, mythology, traditions, languages, culture, and history.

3- Museum-Experience-Design requires following special considerations that put the Interior Design, Communication, Storytelling, Cultural aspects all together in one equation that results in a successful experience.

4- Experience Design process requires putting into consideration that all the experience components: the elements of design (interior design, case design, sound and light effects and signage...etc.), with respect to what the story we want to tell, what the final outcome would be, or how it is related to the things around it and the total effect that we're planning to get.

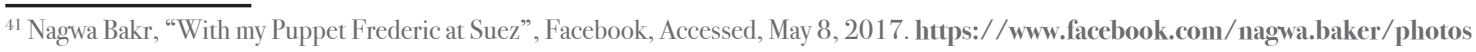


5- The international practices of integrating puppets in museums were very successful. They can be applied in Egypt in a way that suits the Egyptian culture.

6- The Egyptian modern culture has lots of popular puppets, such as (The Karagoz, Boloz, Koronba, El-Leila-El-Kebira, Seasem World, Bougy \& Tumtum... etc), that can be used to perform entertainment and educational functions in museums.

7- Choosing the proper type of puppets helps in communication. This calls for further research and conceptual development.

8- Based on the field study:

A) Puppets have a very strong influence on people:

- Creating a lovely effect of joy.

- Controlling peoples' emotions, grabbing their attention and immersing them in stories that they tell.

- Stimulating memories and taking them back to childhood.

- Consolidating heritage.

- Transferring information smoothly.

B) Puppets had a strong impact on people. They have been able to survive through thousands of years. This proves their power, and ensures their compatibility with children and adults. Since people like puppet theatres, this means that they will make the museum experience very interesting for them.

C) The wide range of puppets can perform everywhere in the museum to achieve an outstanding experience, especially popular puppets

Hence, the linkage meant to be created between puppetry, storytelling, and museum experience design here, is using puppets as a key element in experience design to influence people culturally, connecting all museum departments.

\subsection{Recommendations:}

Museologists shall make use of this power in making puppets tell stories in creative ways. The following projects and activities are recommended:

A) Storytelling Bus: A double-deck bus, equipped with a theatre, to take tourists to museums and sites. On their way, they watch a puppet show about their destination, in order to stimulate their curiosity about what they're going to see. 


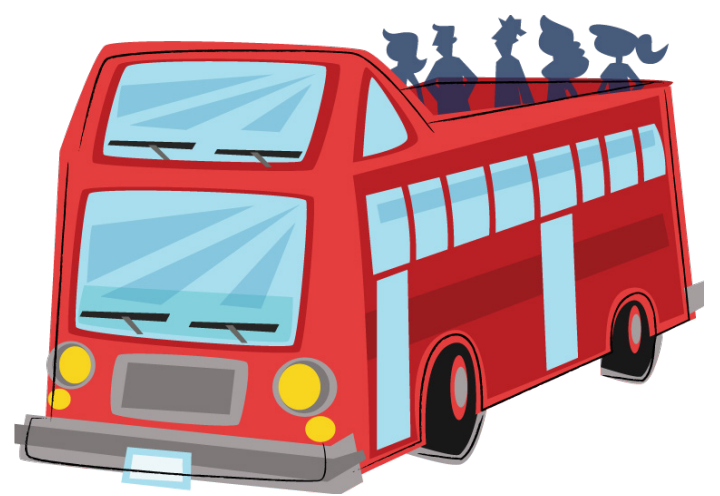

Fig. (34) An imaginary clipart of the storytelling bus ${ }^{42}$

B) Storytelling Programme: Telling the stories of Egyptian famous characters through a steady puppet theatre featured by Marionette puppets.

C) Family Tree Nesting Dolls: This is to make the visitors memorize the relation between generations of famous historical dynasties easier.

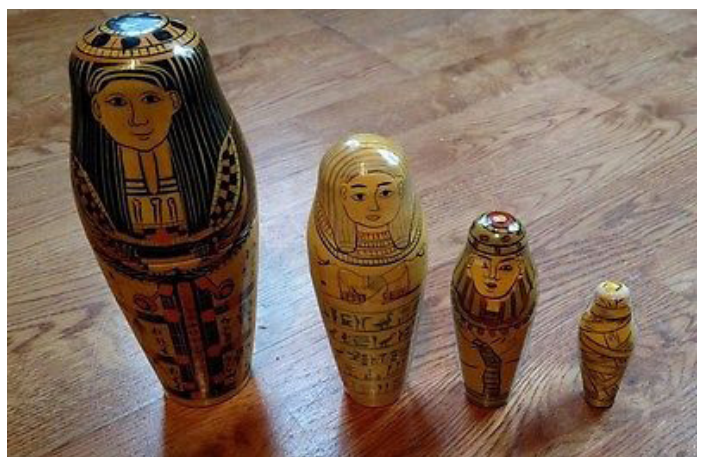

Fig. (35) A set of Egyptian nesting dolls.43

D) Characterization Technology: Interpreting exhibition by an augmented reality puppet that appears suddenly inside the exhibition when visitors stand in front of an object, replacing the curator.

E) Museum Mobile Theatre: A carriage/small car, equipped with a puppet theatre. It will move inside different parts of a museum telling a different story in each stop.

F) Storytelling Diorama: A performance based on a moving puppet that tells the story, placed in a diorama-built-environment.

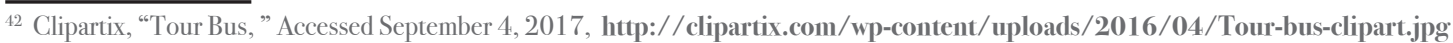


G) Marketing Inspirations: Making models of Egyptian puppets, to be given as souvenirs. Selling puppets at the museum shop will enhance the post-visit experience.

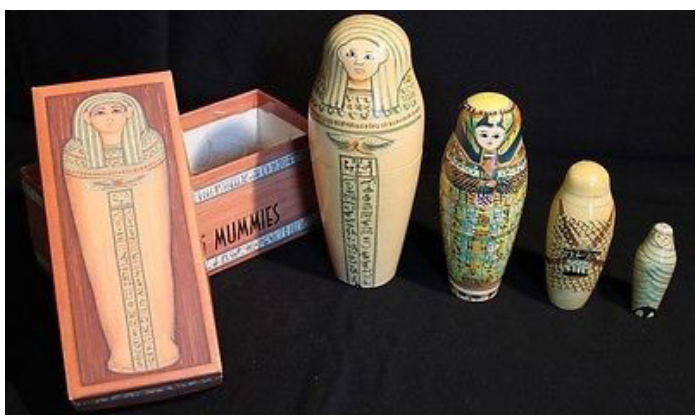

Fig.(36) A set of nesting dolls that tells an ancient Egyptian story ${ }^{44}$

H) Educational Programmes: Teaching visitors how to make different types of puppets.

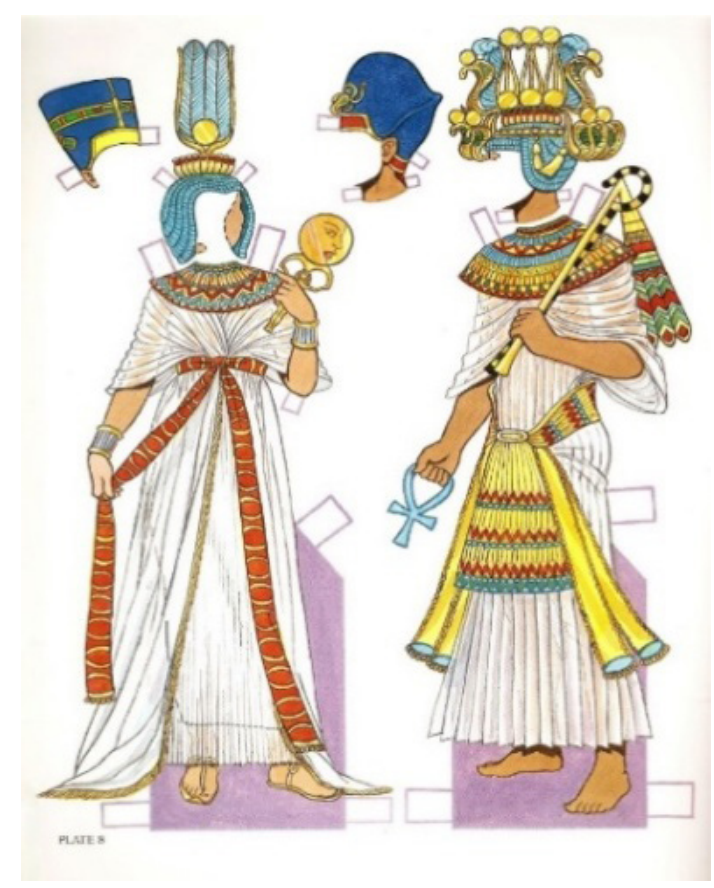

Fig.(37) Paper puppets for museum education ${ }^{45}$

\footnotetext{
${ }^{44}$ Worth Point, "Nesting Mummies Museum," Accessed January 3, 2017, https://thumbs.worthpoint.com/zoom/images1/1/0314/04/nestingmummies-museum-arts-boston_1_e504a156f43f4939d88c71684b602e29.jpg

${ }^{45}$ Pinterest, "Paper Puppets," Accessed February 3, 2017, https://i.pinimg.com/originals/43/c3/7b/43c37b7b09806ab95d96656191d37d82. jpg
} 
- Customized games to facilitate museum interpretation:

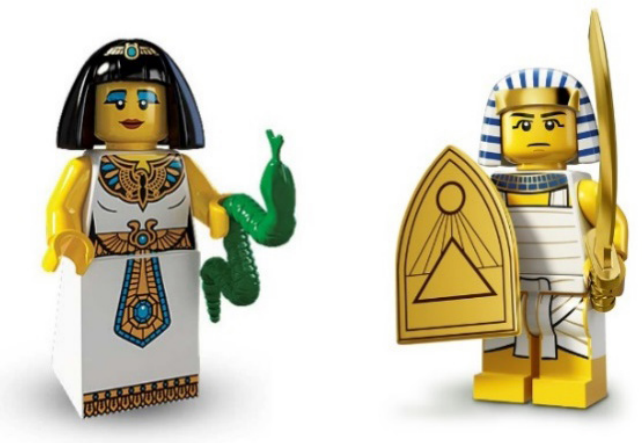

Fig.(38) Lego figures of ancient Egyptian man \& woman ${ }^{46}$

I) 2d Illustrations for books, gifts, \& comics.

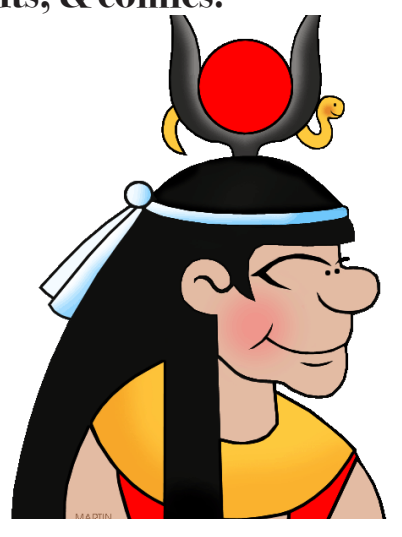

Fig.(39) A comic 2d illustration of an ancient Egyptian women ${ }^{47}$

J) Telling the museum story by cartoon characters.

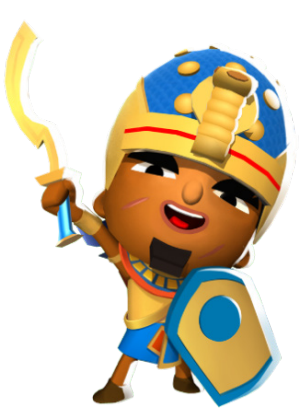

Fig. (40) 3 d character ${ }^{48}$

\footnotetext{
${ }_{46}^{46}$ Lego, "New Sets," Accessed July 16, 2017, https://lc-www-live-s.legocdn.com/r/www/r/catalogs/-/media/catalogs/characters/minifigures/ series\%2013/characters_1488x928_serie13_egyptianwarrior.png?.1.r2=-1483408330

${ }^{47}$ Phillip Martin Clip Art, “Egypt Index,” Accessed August 28, 2017, http://egypt.phillipmartin.info/egypt_hathor.gif

${ }^{48}$ The World of Warriors Wiki, “Egyptian 4.PNG”, Accessed August 27, 2017, http://vignette3.wikia.nocookie.net/world-of-warriors/images/6/63/ Egyptian_4.png
} 
K) Customized puppets to be sold at museum shop.

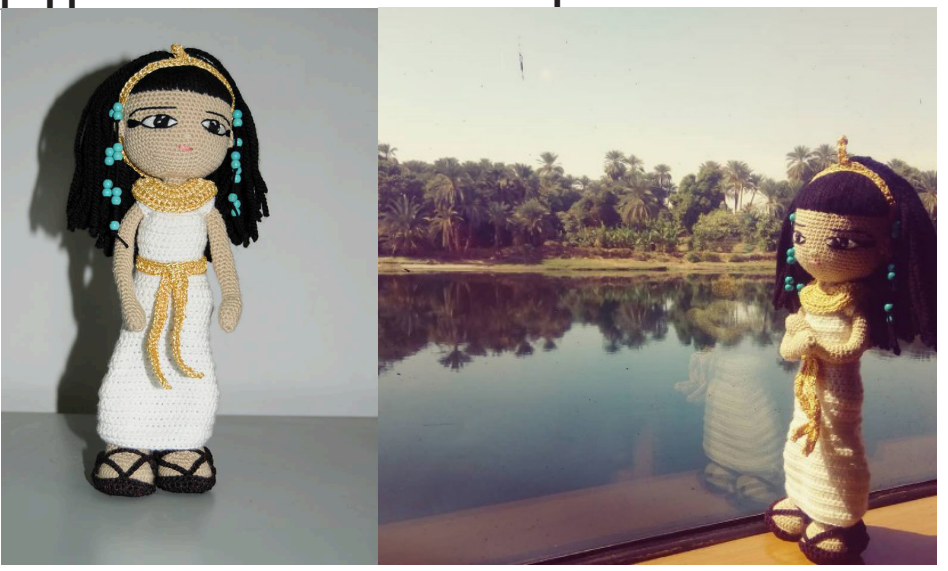

Fig.(41) An Egyptian girl Crochet (Amiguruni) puppet, by Mona Darwish ${ }^{49}$

These suggestions can play a role in enhancing the experience in Egyptian museums. Moreover, collecting and showcasing famous puppets in a specialized museum for puppets will be very interesting.

\section{Bibliography}

- Collins Dictionary, "Puppetry," Accessed September 4, 2017, https://www.collinsdictionary.com/dictionary/ english/puppetry

- E.A. Wallis Budge, "From Fetish to God in Ancient Egypt," Routledge, 2013, 128.

- Emile H. L., and Stefano Marzano, "The New Everyday: Views on Ambient Intelligence". 010 Publishers, 2003, 46.

- Fernando Guimarães, "Puppetry: An Overview”, Pedia Press, 1997, 50.

- Hooper-Greenhill, The Educational Role in Museums, London: Routledge, 1999, 256.

- Joshua J. Mark . "Shabti Dolls: The Workforce in the Afterlife." Ancient History Encyclopaedia. January 18, 2012 , http://www.ancient.eu/article/119/

- Keith Rawlings, "Observation on the Historical development of puppetry," Accessed Mach 3, 2017, http://pages. citenet.net/users/ctmw2400/chapter 1.html

- Marta Teres. "Museums, spaces and museographical resources. Current state and proposals for a multidisciplinary framework to open new perspectives." Spain University of Barcelona. 2015.

- Nermine Moustafa. "Shabti Dolls Displayed at The Material Multure Hall". The Egyptian Museum in Turin. Feb 1, 2016.

- Pamela Erskine-Loftus. Disrupting Design: The Impact of Cultural Contexts. Exhibitionist. Spring 2014.

- Patrick Newbery. "Experience Design is a Perspective not a Discipline." UX Magazine. 2013. http://uxmag.com/ articles/experience-design-is-a-perspective-not-a-discipline

- Phillip Martin Clip Art. “Egypt Index.” Accessed August 28, 2017. http://egypt.phillipmartin.info/egypt_ hathor.gif

- Regan Forrest, "Design Factors in the Museum Visitor Experience" (PhD diss., Australia, The University of Queensland, 2014), 17-19.

- Sanaa El-Bissy, "Shokouku Al-Sindbad Al-balady" (Shokouku The Local Sindbad), Al-Ahram Newspaper, June 7, 2008. http://www.ahram.org.eg/Archive/2008/6/7/Writ1.htm

- Smithsonian Institute, OP\&A, EXHIBITIONS AND THEIR AUDIENCES: ACTUAL AND POTENTIAL, Washington DC, September 2002. 7.

- Texas A\&M University, "Culture," Accessed September 3, 2017, https://tlac.tamu.edu/

- Theater Seat Store, "History of Puppetry," Accessed September 17, 2017, https://www.theaterseatstore.com/ history-of-puppetry

${ }^{49}$ Mona Darwish, "Made by Manaminoooooo," Accessed September 1, 2017, https://www.facebook.com/photo. php?fbid=10155754991 198680\&set=a.431 660458679.2 13329.565918679\&type=3\&theater) 
- The British Museum. “Collection Online: Paddle Doll.” Accessed September 2, 2017.http://www.britishmuseum. org/research/collection_online/collection_object_details.aspx?objectId=1 18802\&partId=1

- The British Museum. “Collection Online: Rag Doll.” Accessed August 18, 2017. http://www.britishmuseum. org/research/collection_online/collection_object_details.aspx?objectId=400067\&partId=1

- The British Museum. "Fieldnotes Storytelling." Accessed February 20, 2017. http://www.britishmuseum.org/ PDF/storytelling_resource_changed_font_size.pdf

- THE MET. "Paddle Doll." Accessed September 1, 2017. http://www.metmuseum.org/art/collection/ search/544216

- The World of Warriors Wiki. "Egyptian 4.PNG.” Accessed August 27, 2017. http://vignette3.wikia.nocookie. net/world-of-warriors/images/6/63/Egyptian_4.png

- UNESCO Multimedia Archives eServices. “Culture: Intangible Heritage, Karagöz.” Accessed August 12, 2017, http//:www.unesco.org/archives/multimedia?/pg=33\&s=films_details\&id=365

- Unknown Author, "Shokouku with his famous Aragoz and his look-alike puppet”, Wikipedia, Accessed February 17, 2017 https://ar.wikipedia.org/wiki/Mahmoud_Shokoko 